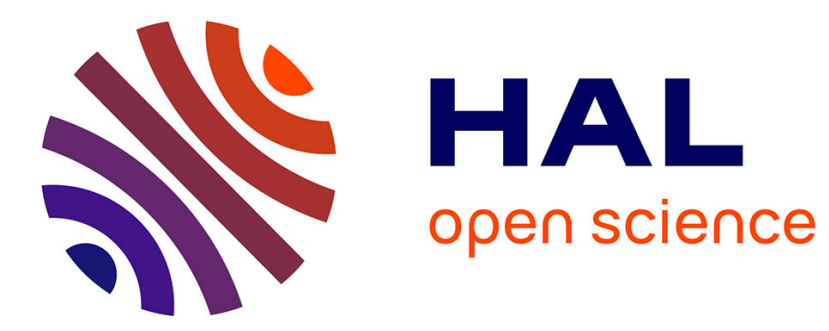

\title{
Global warming and the weakening of the Asian summer monsoon circulation: assessments from the CMIP5 models
}

\author{
K. P. Sooraj, Pascal Terray, Milind Mujumdar
}

\section{- To cite this version:}

K. P. Sooraj, Pascal Terray, Milind Mujumdar. Global warming and the weakening of the Asian summer monsoon circulation: assessments from the CMIP5 models. Climate Dynamics, 2015, 45 (1), pp.233-252. 10.1007/s00382-014-2257-7 . hal-01135665

\section{HAL Id: hal-01135665 \\ https://hal.science/hal-01135665}

Submitted on 27 May 2016

HAL is a multi-disciplinary open access archive for the deposit and dissemination of scientific research documents, whether they are published or not. The documents may come from teaching and research institutions in France or abroad, or from public or private research centers.
L'archive ouverte pluridisciplinaire HAL, est destinée au dépôt et à la diffusion de documents scientifiques de niveau recherche, publiés ou non, émanant des établissements d'enseignement et de recherche français ou étrangers, des laboratoires publics ou privés. 


(1)

Global warming and the weakening of the Asian summer monsoon circulation: Assessments from the CMIP5 models Pune 411008, India

${ }^{2}$ Sorbonne Universites (UPMC, Univ Paris 06)-CNRS-IRD-MNHN, LOCEAN Laboratory, 4 place Jussieu, Paris, France

${ }^{3}$ Indo-French cell for Water Sciences, IISc-IITM-NIO-IRD Joint International Laboratory, IITM, Pune 411008, India

(1)

June, 2014

22 Corresponding author address:

3 Sooraj K. P.

24 Centre for Climate Change Research

5 Indian Institute of Tropical Meteorology

26 Pune 411008, India

27 e-mail: sooraj@tropmet.res.in 
Global warming and the weakening of the Asian summer monsoon circulation: Assessments from the CMIP5 models

\section{Sooraj K P ${ }^{1}$, Pascal Terray ${ }^{2,3}$ and Mujumdar $\mathbf{M}^{1}$}

\begin{abstract}
The evolution of the Asian Summer Monsoon (ASM) in a global warming environment is a serious scientific and socio-economic concern since many recent studies have demonstrated the weakening nature of large-scale tropical circulation under anthropogenic forcing. But, how such processes affect the ASM circulation and rainfall is still a matter of debate.
\end{abstract}

This study examines the climate model projections from a selected set of Coupled Model Inter-comparison Project 5 (CMIP5) models to provide a unified perspective on the future ASM response. The results indicate a robust reduction in the large-scale Meridional Gradient of Temperature (MGT) at upper levels (200 hPa) over the ASM region, associated with enhanced ascendance and deep tropospheric heating over the equatorial Pacific in the future climate. The differential heating in the upper troposphere, with concomitant increase (decrease) in atmospheric stability (MGT), weakens the ASM circulation, promotes a northward shift of the monsoon circulation and a widening of the local Hadley cell in the eastern Indian sector. An examination of the water vapour budget indicates the competing effects of the thermodynamic (moisture convergence) and dynamics processes (monsoon circulation) on future ASM rainfall changes. The former component wins out over the later one and leads to the intensification of Indian monsoon rainfall in the CMIP5 projections. However, the diagnostics further show a considerable offset due to the dynamic component.

Key words: Asian Summer Monsoon, meridional gradient in deep tropospheric heating, atmospheric stability, thermodynamic and dynamic components 


\section{Introduction}

\subsection{Background}

The Asian Summer Monsoon (ASM) is one of the major components of the global climate system and provides fresh water resources for the most densely populated countries in the world such as India. The ASM constitutes the major portion of the annual mean precipitation over the Indian subcontinent. Given its profound socioeconomic importance, a key problem lies in determining the response of regional monsoon hydrological cycle to global climate change.

However, solving this issue is a big challenge for the current climate models, as there are still a lot of uncertainties and spread affecting the ASM circulation and precipitation in both historical simulations and future climate projections undertaken in the framework of the United Nations Intergovernmental Panel on Climate Change (IPCC; AR4 report Sections 10.3.5.2). Several climate modelling studies suggest that greenhouse warming is likely to intensify the monsoon precipitation over the ASM domain (Meehl and Washington 1993; Bhaskaran et al. 1995; Douville et al. 2000; May 2002, 2004, 2010; Turner et al. 2007; Turner and Annamalai 2012). However, many other studies shared a contrary opinion, highlighting a significant weakening of the large-scale monsoon circulation which may offset the increase in precipitation (Ashfaq et al. 2009; Krishnan et al. 2013). This paradox is often referred in the literature as the "wind-precipitation paradox" (Kitoh et al. 1997; Stephenson et al. 2001; Gastineau et al. 2008; Stowasser et al. 2009; Cherchi et al. 2010; Ueda et al. 2006; Ogata et al. 2014; Krishnan et al. 2013). Some studies also indicated that the precipitation response may not be directly associated with the circulation changes in the climate projections since changes in atmospheric moisture and moisture transport play a vital role in the future ASM rainfall abundance (Kitoh et al. 1997, 2013; Douville et al. 2000, 2002; Ashrit et al. 2005; Meehl and Arblaster 2003; May 2002; Hsu et al. 2012). 
The projected global surface warming scenario is rather more rapid over the land than the ocean, leading to a greater continental-scale land-sea thermal contrast (IPCC; AR4 report Sections 10.3.5.2; see section 3.2). So a simple notion arising from the classical land-sea contrast mechanism of monsoon (Fu and Fletcher 1985; Webster et al. 1998) is that the ASM circulation will be relatively stronger in the future climate projections. However, the evidences so far seen from climate simulations are not so obvious ( $\mathrm{Ma}$ and $\mathrm{Yu}$ 2014; Krishnan et al. 2013). In this context, it is important to note that apart from the classical definition involving near-surface temperature ( $\mathrm{Fu}$ and Fletcher 1985), more recent studies have highlighted the dominant role played by the mid-upper (200-500 hPa) tropospheric thermal contrast in driving the monsoon (Dai et al. 2013). Some of the previous studies also shared similar viewpoints on the influence of tropospheric thermal contrast on ASM variations (Li and Yanai 1996; Yanai and Li 1994; Ueda et al. 2006; Holton 2004; He et al. 2003; Xavier et al. 2007). Their fundamental argument is that the establishment and maintenance of the monsoon circulation are closely related to the evolution of the upper tropospheric temperature field trough the thermal wind relation (Dai et al. 2013). Further, the meridional gradient in upper tropospheric temperature (MGT) is proportional to the meridional gradient of deep tropospheric heating, and could cause acceleration of deep tropospheric monsoon circulation. According to Xavier et al. (2007), the change in sign of MGT signals the setting up of the off-equatorial large-scale deep heat source and the associated Gill-type atmospheric response leads to the strengthening of cross-equatorial and low-level monsoon flow (Gill 1980). In contrast, the classical land-sea contrast mechanism of monsoon involving surface temperature could only produce a shallow circulation. Bayr and Dommenget (2013) have provided an updated global view on this land-sea contrast and according to them the land-sea contrast is more precisely described through the temperature gradient of the whole troposphere rather than from the surface. 


\subsection{Present study}

Most of the aforementioned studies assessed the future ASM changes through the use of either one specific model or a simple ensemble mean from many climate models and thus are subjected to uncertainties due to various interpretations (based on the choice of model data sets) or to wide variations among the selected model projections (Kripalani et al. 2007; Annamalai et al. 2007; Turner and Slingo 2009; Krishna Kumar et al. 2010; Fan et al. 2010; Seo and Ok 2013). Thus, assessment of future ASM changes has remained ambiguous so far. Furthermore, future changes predicted from climate models highly rely on the simulations of the present-day climate, which have many deficiencies (e.g., Allen and Ingram 2002; Knutti and Sedlacek 2013). Therefore for an improved future change assessment, a prerequisite is a thorough evaluation of the simulated present-day climate as well as an improved selection of climate models that brings out the ASM to a better realism. The present study intends to do this by focusing on the credence and significance of future monsoon projections.

Recently, numerous climate modelling groups took part in a coordinated climate model experiments, comprising the fifth phase of the Coupled Model Inter-comparison Project (CMIP5). Under this project, a series of experiments were performed: the $20^{\text {th }}$ century historical runs and $21^{\text {st }}$ century climate projections with four different representative concentration pathway scenarios (Taylor et al. 2012). Initial analysis of these experiments has shown that the CMIP5 models are comparatively better than the CMIP3 in simulating AsianAustralian monsoon system, especially its seasonal cycle (Li et al. 2012; Sperber et al. 2013; Jourdain et al. 2013). Lee and Wang (2012) further observed that CMIP5 ensemble mean better simulates the global monsoon intensity and area than the corresponding CMIP3 ensemble average. Additionally, some recent studies showed a slight improved representation of El Niño Southern Oscillation (ENSO) in CMIP5 models (e.g., Bellenger et al. 2013). Since ENSO is one of the most important forcing for the ASM, this may imply a better 
representation of ENSO-monsoon relationship in CMIP5 models. In this regard, Jourdain et al. (2013) recently pointed that about 11 CMIP5 models have relatively good skill in simulating the ENSO-monsoon relationship. Finally, CMIP5 models have improved response to natural forcing and aerosols than CMIP3 coupled models (Yeh et al. 2012; Lee and Wang 2012).

A comprehensive study focusing specifically on future changes of the ASM in CMIP5 models is still missing to the best of our knowledge. The objective of this study is thus to investigate the impacts of climate change on ASM using CMIP5 coupled models that participated in the $5^{\text {th }}$ Assessment Report (AR5) of the IPCC (2001, 2007). The improvements in CMIP5 against CMIP3, as mentioned above, may bring more robustness and confidence in ASM projections. We restrict mainly our attention to a subset of CMIP5 models that have a better representation of the present-day mean and variability of ASM precipitation. The critical factors associated with the ASM system in the future projections are then carefully examined viz., rainfall, circulation, monsoon seasonality, MGT and water vapour budget. In particular, we focus on the linkage between MTG and ASM circulation (as described in section 1.1) in the future climate. We also seek to establish the relative contributions of thermodynamic and dynamic components to the governing water vapour balance over ASM region, in order to provide a better physical understanding of the processes governing the projected ASM rainfall changes.

The paper is organized as follows. Section 2 presents a brief description of the models, data and methodologies. Section 3 provides an analysis of the present-day monsoon climate and its response in climate change experiments. Section 4 examines the mechanisms responsible for the weakened monsoon circulation in future climate. Section 5 explains the possible mechanism for the enhanced ASM rainfall, followed by discussion and summary in section 6. 


\section{Data and Methodology}

\subsection{Datasets}

We use the historical and Representative Concentration Pathway (RCP) 4.5 climate experiments from 19 coupled general circulation models (CGCM) contributing to CMIP5 (Taylor et al. 2012; http://pcmdi9.1lnl.gov). The models and their descriptions are provided in Table 1 . The historical experiments (i.e. the $20^{\text {th }}$ century) are forced by observed changes in natural and anthropogenic sources, which also include time-varying land-cover. The RCP4.5 experiments are driven by emission scenarios assuming that the net radiative forcing will increase to about $4.5 \mathrm{Wm}^{-2}$ by the end of $21^{\text {st }}$ century and stabilize thereafter. This is considered as a "central" scenario in CMIP5 (Taylor et al. 2012).

The 20-year mean during 1980-1999 in historical simulations defines the present-day climatology, the mean during 2080-2099 in RCP 4.5 defines the future climatology, and their difference represents the future change under global warming. Note that each model dataset differs in horizontal grids; therefore, for ease of comparison, the datasets corresponding to all simulations (historical as well as RCP 4.5 runs) are re-gridded into a $2.5^{\circ} \times 2.5^{\circ}$ horizontal grid using a first-order remapping procedure implemented in the Climate Data Operators (https://code.zmaw.de/projects/cdo) and are then compared against the observed and reanalysis products. It should be further noted that all the diagnostics are performed only for the boreal summer season (June to September, JJAS). Our diagnostics made use of several monthly variables, including surface temperature, rainfall, atmospheric circulation and radiative fluxes (longwave and shortwave fluxes at the surface and top of the atmosphere).

We use the NCEP/NCAR reanalysis products (Kalnay et al. 1996), which have a horizontal resolution of $2.5^{\circ}$ longitudes and $2.5^{\circ}$ latitudes, to depict the atmospheric circulation and temperature characteristics. The observed monthly precipitation datasets are 
from the Global Precipitation Climatology Project (GPCP version 2.1, Huffman et al. 2009).

The period of analysis is from 1980 to 1999 .

\subsection{Selection of good models}

Following the prelude, a detailed evaluation of the model's ability to capture the present-day climate and the subsequent model selection is attempted here. The performance of 19 CMIP5 CGCMs for the present-day climate is assessed through the use of two Taylor diagrams (Taylor 2001), based on the fidelity in simulating JJAS rainfall climatology and variability over a broad $\mathrm{ASM}$ region $\left(30^{\circ} \mathrm{E}-120^{\circ} \mathrm{E}\right.$ and $\left.30^{\circ} \mathrm{S}-30^{\circ} \mathrm{N}\right)$. The choice of this large domain follows the observational evidence that ASM consists of multiple local rainfall maxima centred over the Bay of Bengal region, the tropical western Pacific and the eastern equatorial Indian Ocean, and a realistic representation of these rainfall centers is vital for assessing the Indian summer monsoon variability (Annamalai and Liu 2005; Annamalai et al. 2007).

The Taylor diagrams succinctly describe the coherence between models and observations in terms of their spatial pattern correlation, their root-mean-square (RMS) difference, and the ratio of their standard deviations (Taylor 2001; Joseph et al. 2010). In Figure 1, the radial distances from the origin are proportional to the standard deviation of the model field, normalized by the observed standard deviation. This radial distance is unity, when the model and observed standard deviations coincide with each other. The distance from the reference point (denoted by REF in Fig.1) to the plotted point measures the RMS difference and closeness of the plotted point to REF suggests less RMS difference. The pattern correlation (between the model and observation) is the cosine of the azimuthal angle made with the abscissa in Fig.1. If it is unity, then the point will lie along the horizontal axis.

It is clear from the figures that there is significant inter-model spread in capturing the observed climate statistics, particularly for the interannual variability (see Fig. 1b). Taking 
note of this large spread and the related uncertainty in future monsoon projections, an optimal selection of reliable (or one can say "optimally the good") models among 19 CGCMs is derived based on the following criteria: (i) the pattern correlation in the climatological mean field (Fig. 1a) is above 0.65, (ii) the pattern correlation in the inter-annual standard deviation field (Fig. 1b) is above 0.6, and (iii) spatial inter-annual standard deviation ratio (the spatial standard deviation normalized by the observed spatial standard deviation) is within $1.0 \pm 0.2$. Similar criteria are used by Seo and Ok (2013) for selecting the best CMIP3 models in their recent study on East Asian Monsoon future projections. Only the models satisfying all three criteria are used for the full assessment of the ASM future projections. The duly selected 7 models are highlighted in Table 1. For brevity, these seven models are referred to as the "good" in the subsequent text and their multi-model simple ensemble mean is called hereafter as "ensemble mean" or "ENS". Note here that 3 out of the seven selected models (GFDLESM-2G, IPSL-CM5A-LR and NorESM1-M) are Earth System Models (ESM). In ESMs, CGCMs are coupled to biogeochemical components so as to account for the carbon surface fluxes between the ocean, atmosphere and terrestrial biosphere carbon reservoirs (Taylor et al. 2012). Note further that we performed similar Taylor diagnostics using CMIP3 models and these selected good models showed better performance in capturing the observed ASM climate statistics compared to their counterparts in CMIP3 models (figure not shown). This again confirms the recent studies that showed improved representation of ASM in CMIP5 models (e.g., Sperber et al. 2013).

Finally, we will also verify some of our results using all the available models in order to test the robustness of monsoon projections and thus to strengthen our conclusions. We demonstrate this using fifteen CMIP5 models (from the 19 models listed in Table 1), for which the necessary wind circulation and temperature fields for both historical and RCP 4.5 simulations were available at the time of our analysis. The excluded models are CSIRO- 
Mk3.6.0, GISS-E2-H, HadGEM2-CC and INM-CM4. The extended ensemble mean

calculated from those 15 models will be referred as "extended ensemble mean" or simply "ENS15 average" in the following sections. Consideration of the ENS15 averages will demonstrate that our results are not very sensitive to our selection procedure and are robust even using a grand ensemble mean of 15 CMIP5 models.

\section{Monsoon climate}

\subsection{Present-day}

As described in the preceding section, there are 7 good models that are optimally considered to perform better out of 19 CGCMs. Figure 2 shows the JJAS mean precipitation and $850 \mathrm{hPa}$ winds computed from observations and the ensemble mean (using these 7 good models, see section 2.2) derived from the historical simulations. The precipitation maxima along the west coast of Peninsular India, southern equatorial eastern Indian Ocean, over eastern India, Bangladesh and Bay of Bengal are well simulated by the ensemble mean (Figs. 2a,b). Also, some of the large-scale circulation features such as the band of easterly winds south of the equator, the low-level Somali jet and the strong westerlies across Arabian Sea and southern India are realistically simulated (Figs. 2d,e). The surface skin temperature distribution (Fig. 3a) shows distinct maxima (greater than $30^{\circ} \mathrm{C}$ ) over the land mass in Northern Africa, the Middle east, India, Pakistan, Afghanistan as well as over the Indian Ocean, Bay of Bengal and tropical west Pacific. The ensemble mean reproduces the basic seasonal pattern of surface temperature contrast where the land is significantly warmer than the ocean in the Indian domain. Further, the pattern and strength of the sea level pressure (SLP) field are captured reasonably well (Figs. 3c,d). The magnitude of the negative SLP gradient from the southern Indian Ocean subtropical anticyclonic high towards the monsoon trough is approximately around $16 \mathrm{hPa}$ (Fig. 3c). Furthermore, the strength and spatial pattern 
of the Hadley circulation, and the upper-level easterly jet stream are also well simulated (figures not shown).

There are systematic errors, however, found in these good models; especially these models have inherent difficulties in capturing the finer regional precipitation details (Fig. 2c). The precipitation over the central Indian landmass is underestimated and the ensemble mean further shows that it is comparable or even smaller than that over eastern Indian Ocean. The precipitation over western Indian Ocean, on the other hand, is amplified and may be partly associated with warm sea surface temperature (SST) biases in the models (Fig. 3b; Bollasina and Ming 2013; Prodhomme et al. 2014a). Further, the observations indicate heavy precipitations along the west coast of the Indian peninsula (concentrated over the Western Ghats barrier) and a rain shadow region over the south-eastern parts on its leeside (Fig. 2b). Although the ensemble mean attempts to capture this detail, it fails to reproduce the observed magnitudes (Fig. 2c). This point towards the coarse resolution of selected CMIP5 models (with a grid size greater than $100 \mathrm{~km}$ in most of the cases), thus posing a major challenge in adequately resolving the fine ASM precipitation features (Krishnan et al. 2013).

As far as the rainfall seasonal cycle over Indian monsoon region $\left(10^{\circ}-25^{\circ} \mathrm{N}, 60^{\circ}\right.$ $100^{\circ} \mathrm{E}$ ) is concerned, all good models depict the transition from May to June, however there are large inter-model spread in the timing of the rainy season with a conspicuous delay in monsoon onset relative to observations (Fig. $2 \mathrm{~g}$ ). Furthermore, the intensity of the simulated monthly precipitation during July-August (observed rainfall peaks in this season) is systematically weaker in most of the selected models (see Table 1 for model details). In addition, there is a significant spread even within the good models in depicting the seasonal cycle of precipitation. Earlier, Annamalai et al. (2007) have noted similar inter-model spread in CMIP3 models in simulating the seasonal cycle. Recently, Sperber et al. (2013) also 
observed systematic errors that are consistent between CMIP3 and CMIP5 models; however the amplitude of the error is smaller in CMIP5 compared to CMIP3.

Apart from these rainfall biases, the low level winds are underestimated (overestimated) over northern (southern) part of the Arabian Sea (see Fig. 2f). This too weak monsoon circulation over the north Indian Ocean in the models is consistent with rainfall errors discussed above. Surprisingly, SLP shows (Fig. 3d) underestimation especially over the Indian subcontinent, with a lowering of surface pressure, in spite of the dry bias and the southward shift of the ASM circulation noted above (Figs. 2c,f). The surface temperature shows warm bias over the tropical areas, especially over the Indian subcontinent and in the ocean upwelling regions (see Fig. 3b) and a cold bias over extratropical Pacific and Atlantic Oceans. The in-situ SLP anomalies over the Indian landmass may probably due to the increase of surface temperature over there.

\subsection{Future response}

Figure 4a shows the ensemble mean patterns of temperature and SLP changes in the future. These patterns are obtained from the difference between the 2080-2099 period in RCP 4.5 and the 1980-1999 historical period (see section 2.1). In the rest of the manuscript, we alternatively use the term anomaly to refer to this difference. While surface temperature increase is ubiquitous, an enhanced land-sea temperature contrast (surface temperature over the land larger than over the ocean) is projected into the future, consistent with earlier results (e.g., Sutton et al. 2007; Annamalai et al. 2007). The surface thermal contrast between the Eurasian continent and tropical Indian Ocean significantly increases in the future climate by about $2^{\circ}-3^{\circ} \mathrm{C}$. Global warming also produces an "El Niño-like" pattern in the equatorial Pacific (e.g., Knutson and Manabe 1994; Annamalai et al. 2007) and a warming as large as $1.5^{\circ} \mathrm{C}$ in the tropical Indian Ocean, while maximum warming of about $2.5^{\circ} \mathrm{C}$ is simulated in the extra-tropical north Pacific Ocean. All the aforementioned features are observed 
consistently across the selected models and in most of the available 15 CMIP5 models (figure not shown). As an example, we tabulated the relative changes in surface temperature over the northern $\mathrm{ASM}$ region $\left(50^{\circ}-100^{\circ} \mathrm{E}\right.$ and Equator- $\left.30^{\circ} \mathrm{N}\right)$; all models show pronounced warming of similar magnitude (see Table $2 b$ ).

The anomaly patterns of ASM rainfall and circulation for both the ENS and ENS15 ensemble averages are shown in Figure 5. There is an overall robust increase in rainfall over most parts of the Indian subcontinent (Figs. 5a and e). This pattern of enhanced rainfall, exceeding the $90 \%$ level of statistical significance, extends from the central Arabian Sea to the whole Bay of Bengal region. Rainfall maxima are found over the north-eastern part of the Indian subcontinent. Also noticeable is the pattern of increased rainfall over the western north Pacific, equatorial Pacific and south-eastern China. For more clarity, we tabulated the relative change in rainfall over northern ASM region for individual models (see Pave estimates in Table 2b). All selected models capture the rainfall intensification with a relative increase of, approximately, $9 \%$ in the ensemble mean.

The future response in low-level winds indicates pronounced easterly anomalies (Figs. $5 \mathrm{~b}$ and f) extending up to $10^{\circ} \mathrm{N}$ over south Arabian Sea and the southern part of Indian subcontinent, pointing to a weakening of the large-scale summer monsoon flow in the future climate (Kitoh et al. 1997; Ashrit et al. 2005). As for the individual models, the relative change in low-level zonal wind over the south Arabian Sea domain (Equator- $10^{\circ} \mathrm{N}$ and $60^{\circ}$ $100^{\circ} \mathrm{E}$ ) ranges from -5 to $-15 \%$, with a $10 \%$ decrease in the ensemble mean (see Table $2 \mathrm{~b}$ ). The prominent westerly anomalies over north Arabian Sea further manifest a concomitant northward shift in monsoon circulation (Menon et al. 2013), but this feature is less significant in the ENS15 average (Fig. 5f). It should be noted that the easterlies or southeasterlies south of the equator are also weakening, especially for the ENS15 average, which substantiates the weakening nature of the large-scale low-level circulation in future climate 
projections. Consistent with these circulation anomalies, there is a large SLP increase (of about $0.6 \mathrm{hPa}$; Figs. $4 \mathrm{~b}$ and c) over the Indian land mass while positive SLP anomalies are weaker and more uniform across the entire Indian Ocean rim, thereby inflicting a decrease in large-scale interhemispheric meridional SLP gradient around the equatorial Indian Ocean. Intriguingly, there is a concomitant decrease in SLP over northern Eurasian landmass, coinciding with the large increase of surface temperature over there (see Fig. 4a), and pointing again to a northward shift of the monsoon circulation and a possible widening of monsoon regional Hadley cell (Seidel and Randel 2007; Siedel et al. 2008). The weakening signature is further evident in the upper-tropospheric tropical easterly jet with anomalous westerlies between the equator and $20^{\circ} \mathrm{N}$ in the Indian region (see Fig. 5c). Future changes in vertical zonal wind shear (defined as difference in zonal wind at $200 \mathrm{hPa}$ and $850 \mathrm{hPa}$ levels) are also indicative of a declining easterly vertical shear over ASM region. This is consistent in all the selected models, as well as ENS15 average; highlighting again the significant weakening of the ASM circulation as measured, for example, from the classical Webster and Yang dynamical index (Figs. 5d and 6a; Webster et al. 1998). Vecchi and Soden (2007), using CMIP3 models, argued that the zonally asymmetric circulation weakens more than the symmetric one. Figures $5 \mathrm{~d}$ and $6 \mathrm{a}$ confirm without ambiguity that the reduction in zonal circulation is valid for the ASM region as well, with all models showing large consensus. However, our subsequent diagnostics (as discussed next) also reveal both a weakening and a widening of the monsoon overturning circulation.

The future response in large-scale monsoon overturning circulation to global warming is examined using the strength of the Monsoon Hadley Circulation (MHC). The average meridional wind in $\mathrm{ms}^{-1}$ at $850 \mathrm{hPa}$ over the region $40^{\circ}-55^{\circ} \mathrm{E}, 10^{\circ} \mathrm{S}-10^{\circ} \mathrm{N}$ is taken as a measure for the lower limb of the $\mathrm{MHC}\left(\mathrm{V}_{850}\right)$. The upper limb of the $\mathrm{MHC}\left(\mathrm{V}_{200}\right)$ is taken as the average meridional wind at $200 \mathrm{hPa}$ over the region encompassing $45^{\circ}-75^{\circ} \mathrm{E}, 20^{\circ} \mathrm{S}-5^{\circ} \mathrm{S}$, 
and $\mathrm{V}_{850}-\mathrm{V}_{200}$ indicates the strength of the MHC (see Joseph et al. 2003). Here the MHC is defined by considering the observed significant out of phase relationship between the upper and lower tropospheric meridional winds (Wang and Fan 1999). The relative future change of the MHC is shown in Table 2b. Almost all the selected models (exception is GISS-E2-R, see Table 1 for model descriptions) indicate a weakening of the interhemispheric Hadley circulation, albeit with a large inter-model spread. Such a possible weakening of the Indian Hadley cell in the context of global warming was also reported in Ashfaq et al. (2009) and Krishnan et al. (2013).

We also analyzed latitude-pressure and longitude-pressure sections of vertical pressure velocity at $500 \mathrm{hPa}$ for a better diagnosis of the evolution of the zonal and meridional circulations in the RCP 4.5 scenario (Figs. 6b and c). Most of the models (e.g. the selected models as well as the ENS15 average) indicate a weaker ascending motion over the southeast Indian Ocean, while no significant changes are found between $5^{\circ}$ and $20^{\circ} \mathrm{N}$. Most importantly, there are upward velocity anomalies northward of $20^{\circ} \mathrm{N}$ in the ASM region for the projected changes (Fig. 6c). This is consistent with the positive rainfall anomalies over the northeastern part of the Indian subcontinent in the RCP 4.5 scenario (see Figs. 5a and e) and is again suggestive of a widening of the local Hadley cell during boreal summer in warmer climate (Seidel and Randel 2007; Siedel et al. 2008). But, again, there are considerable inter-model differences in the strength and locations of anomalous vertical motion, suggesting that future change of regional monsoon Hadley cell, in response to global warming, is model dependent (Douville et al. 2002; Fan et al. 2012). Interestingly, Fig. 6b also displays upward velocity anomalies over the equatorial Pacific with two maxima located, respectively, in the western and eastern sides of the basin. The rainfall projected changes over the equatarial Pacific (figure not shown) confirms that the primary maxima is associated with stronger ascending motion and positive rainfall anomalies (around $1 \mathrm{~mm} /$ day 
between $150^{\circ} \mathrm{E}-150^{\circ} \mathrm{W}$, figure not shown for brevity) over the Pacific warm pool, while the secondary maxima is indicative of a weaker subsidence in the eastern side of the Pacific basin consistent with a slowdown of the Pacific Walker circulation (Fig. 6a).

In brief, the aforementioned indicators unequivocally suggest that global warming weakens the large-scale monsoon circulation and induce a widening of the regional Hadley cell in the eastern part of the ASM domain. In the next sections, we examine the mechanisms responsible for the weakened monsoon circulation and rainfall enhancement in future climate.

\section{Processes causing slowdown of the ASM circulation}

Having noted the thermo-dynamical linkage between MGT and the large-scale ASM circulation (see section 1.1), we will explore it further by assessing the nature of this relationship in future climate. Our definition of MGT follows from Xavier et al. (2007), but with some slight differences in the domain definitions, taking into consideration the spatial patterns of the seasonal variability of upper tropospheric temperature (figure not shown). We denote TT for the tropospheric temperature averaged between $200 \mathrm{hPa}$ and $600 \mathrm{hPa}$ levels. The MGT is subsequently defined based on the reversal of TT between a northern box $\left(50^{\circ}\right.$ $\left.100^{\circ} \mathrm{E}, 30^{\circ}-45^{\circ} \mathrm{N}\right)$ and a southern box $\left(50^{\circ}-100^{\circ} \mathrm{E}, 15^{\circ} \mathrm{S}-10^{\circ} \mathrm{N}\right)$. These two regions are chosen such that their TT difference (which is MGT) exemplifies the large-scale heating gradient driving the ASM circulation. Ueda et al. (2006) also used similar definitions, but considering the inter-hemispheric upper tropospheric thermal contrast (between the Tibetan Plateau, $35^{\circ}$ $45^{\circ} \mathrm{N}, 60^{\circ}-100^{\circ} \mathrm{E}$ and the tropical Indian Ocean, $\left.10^{\circ} \mathrm{S}-10^{\circ} \mathrm{N}, 60^{\circ}-100^{\circ} \mathrm{N}\right)$, for analyzing the future change in ASM.

We then carried out the TT diagnostics in CMIP5 good models by examining its structure over the ASM region, to ascertain its importance as a driving force of ASM in future climate (Fig. 7). The present day TT distribution in the ENS average illustrates the role 
of latent heat release, associated with the ASM rainfall, as a major contributor to the TT spatial pattern in the Indo-Pacific region (Fig. 7a) in agreement with previous studies (Xavier et al. 2007). Figure $7 \mathrm{~b}$ shows the projected change of the TT during boreal summer. The increase in tropospheric heating over the tropical belt is rather uniform as expected (Wu et al., 2001), however the increase of TT over Eurasian continent is reduced and leads to a weaker MGT across ASM domain.

Observations and model studies also indicated that the global warming signal in the upper troposphere is generally stronger than in the lower troposphere, with maxima in the tropical upper troposphere (e.g., Santer et al. 2008; Xu and Emanuel 1998; Lu et al. 2008; Bayr and Dommenget 2013).

To further demonstrate this feature, the vertical structure of the future change in temperature is examined over the two boxes used to define the MGT (one box along $50^{\circ}$ $100^{\circ} \mathrm{E}, 30^{\circ}-45^{\circ} \mathrm{N}$, see Fig. $7 \mathrm{c}$ and another along $50^{\circ}-100^{\circ} \mathrm{E}, 15^{\circ} \mathrm{S}-10^{\circ} \mathrm{N}$, see Fig. $\left.7 \mathrm{~d}\right)$. It is evident that, at upper levels, the future tropospheric warming over the tropical Indian Ocean exceeds that over the entire Eurasian continent for most selected CMIP5 models. This reduction in MGT at upper levels is conceivable in the ENS15 average as well. Therefore, the pronounced decrease in MGT in the upper troposphere may in turn weaken the ASM circulation (Dai et al. 2013). Recently, Bayr and Dommenget (2013) also presented similar arguments while addressing the causes of the weakening of large-scale tropical circulation during climate change. They argued that large-scale response of the tropical circulation (their variable of interest is SLP) is related to the tropospheric (i.e. entire troposphere) land-sea warming contrast, which according to them is evident in all CMIP3 models. Their results coincide with our conclusions using MGT in CMIP5 models. Our present results are also consistent with an earlier study by Ueda et al. (2006) who noted a decrease in interhemispheric thermal contrast at upper-levels, while analyzing the future change in ASM 
circulation using CMIP3 models. Recently, Ogata et al. (2014) also consistently found

427

428

429

430

431

432

433

434

435

436

437

438

439

440

441

442

443

444

445

446

447

448

449

450 decreased MGT in CMIP5 models.

Earlier, we have observed reduced upward motion and decreased rainfall over the equatorial Indian Ocean and enhanced rainfall over the northern part of the ASM domain (see Figs. 5a,b and 6b,c). So the decreased MGT at upper levels (e.g. $200 \mathrm{hPa}$ ) is probably not directly related to the local pattern (e.g. Indian region) of deep convective heating. On the other hand, the MGT at upper levels in the Indian areas is highly sensitive to the extent of tropical Pacific SST warming as the tropical TT anomalies are largely controlled by the Pacific SST evolution (Sobel et al. 2002; Prodhomme et al. 2014b). The El-Niño like SST evolution and the associated increase of vertical motion and rainfall over the Pacific warm pool in the RCP 4.5 scenario imply a tropospheric heating in this region (Figs. 4a and 6b). We further hypothesized that the TT increase in this region is instrumental in explaining the reduced MGT in the Indian areas at upper levels, as atmospheric wave dynamics tend to spread the Pacific TT anomalies to other tropical regions (Wu et al. 2001; Su and Neelin 2002).

However, a closer inspection of the vertical temperature profiles in Figs. 7c and d points to a concomitant significant reversed evolution of the MGT in the lower troposphere (e.g. below $600 \mathrm{hPa}$ ). This suggests a strengthening of the monsoon circulation at lower levels, which agrees well with the widening of the regional Hadley cell in Fig. 6c, with downward (upward) motion over the southeast Indian Ocean (the northern part of the Indian subcontinent). These apparent opposite MGT changes at upper and lower levels suggest that the ASM circulation reverses between the lower and upper troposphere as well, as discussed recently by Ma and Yu (2014). These competing effects further complicate the assessment of the ASM evolution in a global warming scenario and may also explain the contradictions found in the literature on this topic. 

weakening of the tropical mean circulations is induced by increased atmospheric static stability (Knutson and Manabe 1995; Held and Soden 2006; Vecchi et al. 2006; Vecchi and Soden 2007; Krishnan et al. 2013). Stated in detail, the increase in tropospheric moisture is a robust change under global warming as relative humidity remains relatively unchanged (Held and Soden 2006). The resultant increase in moisture transport causes the rainfall to increase. However, the increasing moisture holding capacity of air in a warmer world is not followed by an equivalent intensification of the hydrological cycle (Held and Soden 2006). Thus, tropical circulation may weaken if the rate of rainfall increase is much slower than the rate of increase in moisture content in response to rising surface temperature, as controlled by the Clausius-Clapeyron relationship (Cherchi et al. 2010).

To further understand these thermodynamic arguments in the ASM context, we refer

to Tables $2 \mathrm{a}$ and $\mathrm{b}$, where values of some relevant time mean variables averaged over the north ASM region $\left(50^{\circ}-110^{\circ} \mathrm{E}, \mathrm{Eq}-30^{\circ} \mathrm{N}\right)$ are presented for the selected models. For better clarity, we further displayed the vertical profile of area averaged potential temperature changes over the same domain for the selected models (Fig. 8a). The percentage increase of rainfall (see Pave in Table 2b) and evaporation (see Evap in Table 2b) for the ensemble mean in the future climate relative to present-day climate is less than $9 \%$, whereas the corresponding change in vertically integrated total column water vapour content is higher by about $17 \%$ (see CWC in Table 2b), which implies a weakening of the ASM circulation 471 following Held and Soden (2006). At the same time, it is interesting to note that the atmospheric stability (defined as the potential temperature difference between $200 \mathrm{hPa}$ and $1000 \mathrm{hPa}$ over the monsoon domain, see Table $2 \mathrm{~b}$ ) shows a relative increase of about $10 \%$ in the ensemble mean, which is quite consistent with the weakening of the monsoon circulation described in the previous section. The vertical profile of potential temperature further 
substantiates this increase in atmospheric stability across all the models, with the larger

477 increase occurring in the upper troposphere (Fig. 8a). In the same figure, we have also included the analysis over a broader ASM domain $\left(30^{\circ}-120^{\circ} \mathrm{E}\right.$ and $30^{\circ} \mathrm{S}-30^{\circ} \mathrm{N}$, see dotted lines in Fig. 8b), which also depicts a similar signature. Our results are consistent with Fan et al. (2012). Using selected CMIP3 models, they came with an argument that the increased latent heating in the mid-troposphere associated with enhanced future precipitation, may induce an increase in the lower to middle level dry static stability and thus inhibits the monsoon circulation. Thus, the dry static stability over ASM region under global warming increases as the temperature and moisture increase, eventually weakening the large-scale monsoon circulation.

Large-scale changes in precipitation require compensating changes in radiative heating of the surface and troposphere (Vecchi and Soden 2007). In other words, the sensible and latent heat energy exchanges between the surface and atmosphere should be balanced by the radiative cooling of the atmosphere. So efforts to understand mean atmospheric response to a warmer climate is not complete without addressing its coupling with the radiative energy balance. We analysed here the net radiative energy flux into the atmospheric column for all good models. Note that the net radiative flux is defined here as the difference between surface and top of the atmosphere, following the formulation of Su and Neelin (2002). The ensemble mean showed an increased atmospheric radiative cooling of about $4 \%$ in the future climate relative to present-day climate, with individual model values ranging between 2 to $9 \%$ (tabulated values for each model are not shown for brevity). It is noted that the radiative cooling of the atmosphere is compensated by a proportionate increase in rainfall or condensational heating. But an important point is that for all the models, the atmospheric radiative cooling never increases as rapidly as the tropospheric moisture (on similar lines with rainfall). CMIP3 model studies also indicate that radiative cooling increases more 
slowly than the atmospheric moisture in response to warming (e.g., Vecchi and Soden 2007). As the net radiative flux increased at a slower rate than moisture, again the thermodynamic energy arguments outlined above would consistently imply a weakened monsoon circulation.

\section{Possible mechanism for enhanced ASM rainfall}

In order to account for the enhancement of ASM precipitation in the future climate despite weaker monsoon circulation, water vapour budgets are analyzed using the following decomposition, i.e., future ASM rainfall change $(\Delta P)$ is decomposed into

$$
\Delta P \sim(\Delta \omega \cdot \bar{q}+\bar{\omega} \cdot \Delta q)
$$

where $\mathrm{P}$ denotes the precipitation, $\mathrm{q}$ is surface specific humidity, $\omega$ is the Lagrangian pressure tendency at $500 \mathrm{hPa}$ (a measure of atmospheric vertical velocity), and the overbar and $\Delta$ denote the present-day climatology and change in future climate, respectively. Our budget estimation also uses the convention that the upward vertical pressure velocity is positive. The underlying assumption for equation (1) is that precipitation is produced by air that is being pumped from the boundary layer (through means of ascending motion) into the free troposphere where most of the vapour condenses to form precipitation (Held and Soden 2006). The two terms on the right hand of the equation (1) represent the dynamic and thermodynamic components, respectively. A similar method of decomposition can be found in Huang et al. (2013). This analysis provides a useful insight into the relative importance of each component and its contribution to the future rainfall change over ASM domain.

Figure 9 shows the decomposition results from equation (1) for the ENS average comprising the good models. Similar results are found with the ENS15 average highlighting the robustness of the results (Figure not shown). Equation (1) well reproduces the broad features of future rainfall changes, especially over the north ASM region encompassing Indian landmass, as demonstrated by the comparison of Figures 9a and d. For providing further confidence to our results, Figure 10 displays the vertical profile of corresponding 
changes in vertical velocity and specific humidity, over the northern (with increased rainfall)

527

528

529

530

531

532

533

534

535

536

537

538

539

540

541

542

543

544

545

546

547

548

549

550 and southern (with decreased rainfall) parts of the region of interest (see Fig. 9a). It shows that our results are robust throughout the troposphere until $300 \mathrm{hPa}$ (for most selected models) and, hence our subsequent inferences remain identical even after performing the vertical integration of equation (1). It is clear from Figure $9 \mathrm{~b}$ that the dynamic component shows large spatial variations (with changes of sign) and hence differs from the rainfall change pattern shown in Figure 9a as far as the Indian subcontinent is concerned. This implies that, in the selected CMIP5 models, low level wind convergence (dynamic factor) contributes less to the future uniform rainfall increase over the north ASM region, especially over the Indian subcontinent. Interestingly, when thermodynamic factor is considered (Fig. 9c) it portrays an increased moisture flux convergence over the ASM region in agreement with the rainfall distribution over the Indian subcontinent (Fig. 9a). Thus, the thermodynamic component mostly explains the ascending motion over the climatological convergence zone of ASM region, thus resulting in increased moisture flux and convergence near the surface. For further demonstration, we calculated the area average (over northern ASM region) of budget components from equation (1) using the ensemble mean (using good models). While thermodynamic component shows a positive contribution $\left(6.1 \times 10^{-5} \mathrm{~Pa} \mathrm{~s}^{-1}\right.$ units $)$ to rainfall changes $\left(0.5 \mathrm{~mm} \mathrm{day}^{-1}\right)$, its dynamic counterpart $\left(-2.5 \times 10^{-5} \mathrm{~Pa} \mathrm{~s}^{-1}\right.$ units $)$ shows a drying effect. Since all the selected models show (Figure 10c) positive moisture anomalies throughout the lower troposphere, the vertical integration of equation (1) will consistently imply the dominance of thermodynamic component in future rainfall changes over northern ASM region $\left(70^{\circ}-100^{\circ} \mathrm{E}\right.$ and Equator $\left.-20^{\circ} \mathrm{N}\right)$. In most of the models, the dynamic component tends to show a drying effect, but not strong enough to counterbalance the thermodynamic changes (see Fig. 10a, with exceptions only in GFDL-ESM-2G). The opposite contribution of these two components may probably explain the differential response in precipitation and 
tropospheric moisture over north ASM region, as noted in section 4. The final implication

552

553

554

555

556

557

558

559

560

561

562

563

564

565

566

567

568

569

570

571

572

573

574

575

from our budget analysis is that the future abundance of Indian monsoon rainfall as seen in

CMIP5 projections is dominated by thermodynamic component rather than its dynamic counterpart. Previous global warming experiments using individual CGCMs also suggest that enhanced thermodynamical changes act to favour the future abundance of Indian monsoon rainfall (e.g., Kitoh et al. 1997; Meehl and Arblaster 2003; Ashrit et al. 2005; Dairaku and Emori 2006). The present study by invoking the water vapour budget argument has provided a more elaborated, but consistent, view of this important result.

\section{Discussion and summary}

\subsection{Discussion}

Recently, some studies (e.g., Chou et al. 2009; Chou and Chen 2014) discussed the global warming mechanisms of tropical precipitation changes in CMIP3 models, by dividing the entire tropics into climatological ascending and descending regions. The ascending regions are further divided based on future rainfall changes, i.e. the zones containing negative (area I) and positive (area II) rainfall anomalies. For the areas with positive rainfall anomalies, they further classified them into enhanced (area IIa) and reduced (area IIb) ascending motions. Refer to Chou et al. (2009) for more details. As per their classification, the area I occurs in the margins of convective zones. The area IIb contains a small portion of the northern Indian landmass, in addition to other analogous regions along the tropics (see Fig. 2a in Chou et al. 2009). However, they did not precisely concentrate on the rainfall change over a specific region, for example, the region surrounding the Indian landmass. A question arises now: how do our present results fit in their discussion on thermodynamic and dynamic contributions to future rainfall changes? Firstly over area IIb, as per their result, the rainfall change is mainly associated with the moisture convergence induced by thermodynamic component. In this region, their results show reduced upward motion at low 
and mid troposphere, while it is enhanced in the upper troposphere. They interpreted these changes as an uplift of tropical convection, which enhances the dry static stability of the atmosphere. This increase in stability overcompensates the increase in low-level moisture and thus tends to reduce the ascending motion. Figure 10a fully supports their interpretation, but for a specific domain over the northern part of ASM. According to them, this imparted negative contribution to the dynamic component, but not sufficient to overcome the thermodynamic contribution and so the overall rainfall is still increased. This coincides with our current findings over the major convection center in north ASM region (see Figure 9).

Secondly over area I (convective margins, coinciding with our south ASM domain of decreased rainfall), where they found most of the decrease in future rainfall, the rainfall change is associated with a pronounced weakening of the ascending motion (Fig. 10b). Their argument is that since thermodynamic component is always positive over climatological ascending regions, the contribution of dynamic component to total rainfall changes must be strongly negative in order to have negative rainfall anomalies. A closer inspection of Figures 9a-b shows a more conclusive evidence of this: negative anomalies in dynamic component, confined over the oceanic convergence zone in south ASM region, which coincides with reduced rainfall. This negative contribution due to dynamic component is further manifested in Figure 10b, with nearly all the models consistently showing descending anomalies throughout the troposphere. Chou et al. (2009) argued that this reduced ascending motion and suppressed precipitation are associated mainly with dry advection from subsidence regions (refer to area III in Chou et al. 2009) into convective margins, which they described as “upped-ante” mechanism (e.g., Neelin et al. 2003; Chou and Chen 2014).

Earlier we noted (e.g. section 5) that the differential response in precipitation and tropospheric moisture, in response to global warming, may be due to the opposite contribution of thermodynamic and dynamic components. It point towards an interesting 
601

602

603

604

605

606

607

608

609

610

611

612

613

614

615

616

617

618

619

620

621

622

623

624

625

observation that the precipitation conversion from water vapour is not effective over north ASM region, which in turn implies the weakening of precipitation conversion efficiency in CMIP5 model projections (Lee and Wang 2012).

\subsection{Summary}

This study investigates the response of ASM system to global warming using two realizations (historical and RCP 4.5) from 19 CGCM simulations archived in CMIP5. The historical run is based on evolving solar forcing and anthropogenic influences from 1850 to 2005, and the climate change experiment (RCP 4.5) assumes stabilization of radiative forcing to $4.5 \mathrm{Wm}^{-2}$ after 2100 .

Taking into account of considerable uncertainty in the monsoon future change as projected by the state-of-the-art CGCMs, seven models were identified for detailed analysis on the basis of fidelity in simulating JJAS rainfall climatology and variability over ASM region. The other CGCMs were also used to test the robustness of the results (the ENS15 average). It is demonstrated that the response to greenhouse warming causes enhanced ASM precipitation by about $9 \%$ in the $21^{\text {st }}$ century (see Figs. 5a and e), while the large-scale ASM flow weakens (see Figs. 5b, c, d and f); thus illustrating again the so called "windprecipitation paradox" in the CMIP5 climate change experiments. Our results further revealed that the future deep tropospheric heating over the Eurasian continent is less pronounced as compared to that of tropical Indian Ocean, thus giving rise to a decrease in MGT at upper levels over the ASM region (see Fig. 7). The accentuated tropospheric warming with resultant increase (decrease) in atmospheric stability (MGT), contributes to weaken the largescale ASM circulation in spite of the enhanced land-sea thermal contrast at the surface. An analysis of approximate water vapour budgets (see Fig. 9) showed that the increase of moisture convergence due to enhanced column integrated water vapour in the atmosphere (thermodynamic processes) appears to be one of the main mechanisms responsible for the 
intensified rainfall, implying the smaller role from low-level wind convergence (dynamic processes). Our interpretation is that the thermodynamic component (moisture increase due to global warming) dominates its dynamic counterpart (weakened monsoon circulation), thus accounting for the future enhancement of ASM rainfall in the CMIP5 models.

It should be worth mentioning here that although all the selected good models invariably suggest a likely increase of static stability over ASM region in the future due to vertically differential warming, the physical mechanisms controlling upper tropospheric warming has only been suggested here and is not studied in detail. The warming may be partially due to the increased rainfall and condensational heating over the Pacific warm pool in the future climate (Wu et al. 2001). Some of the earlier studies also attributed similar reasons for this maximum warming in upper troposphere. Lindzen (1990) illustrated that the global warming leads to the rising of the cloud top, and leads to the elevation of the altitude at which there is maximum cumulus heating. On similar lines, Kitoh et al. (1997), Douville et al. (2000) and Fan et al. (2012) suggested increased mid-tropospheric latent heating, in response to the rainfall intensification in future.

It is important to note here that the future changes in other climate phenomena, such as ENSO or Indian Ocean Dipole Mode (IOD), can also modulate ASM. The present study has not addressed the roles of such changes in climate phenomena. Jourdain et al. (2013) have recently evaluated some of these aspects using CMIP5 models. According to them, a set of selected CMIP5 models (those models showing limited biases with regard to monsoonENSO relationship) produce significantly more summer rainfall in India and South Asian region during the twenty-first century compared to the historical period. Their results show a rainfall increase of 5 to $20 \%$ across the models, which is consistent with our results.

The selected CMIP5 models used in this study have horizontal resolution varying from $1.25^{\circ}$ to $3.75^{\circ}$. Such a coarse resolution may not be sufficient to simulate realistically all 
the important processes regulating the ASM system, particularly those associated with the orography, the western Ghats or the precipitation extremes (Sabin et al. 2013). Recently, Ashfaq et al. (2009) and Krishnan et al. (2013) showed the weakening of large-scale ASM overturning circulation using (regional or global) warming simulations from ultra-high resolution models (with $20 \mathrm{~km}$ horizontal resolution) consistent with our results. However, these ultra-high models also simulate decreasing summer precipitation in key areas of south Asia, especially over the western Ghats, under global warming scenarios; results which are not consistent with the coarse CMIP5 projections analysed here. The specific reasons for these discrepancies are not clear and need to be investigated, especially in light of thermodynamic and dynamic components. Nevertheless, these results are based on time slice experiments using prescribed SST and as per many studies (e.g., Douville 2005; Copsey et al. 2006; Krishnan et al. 2010, 2013), this type of sensitive experiments has inherent limitations in simulating the coupled climate processes over ASM region, compared to transient coupled model runs. Hence, these results may be subjected to uncertainties in specifying future SST distributions and its subsequent feedbacks involving convection, particularly over the tropical Indo-Pacific domain, in spite of the improved simulation in other aspects of the ASM system. In other words, the question of the ASM changes under global warming is far from being settled. Continued effort in model development and deeper exploration of the impact of ultrahigh resolution on the ASM changes in climate projections, probably hold the key for solving these incertitudes about the ASM rainfall changes under global warming.

Nevertheless, the insights gained from the present study are beneficial for the ongoing Coordinated Regional Downscaling Experiment (CORDEX, http://wcrpcordex.ipsl.jussieu.fr/) which is an international coordinated framework to produce an improved generation of regional climate change projections world-wide (based on CMIP5 simulations) for input into impact and adaptation studies. Precipitation downscaling, by 
676 improving the coarse resolution and poor representation of precipitation in global climate 677 models, supports user communities to evaluate the possible hydrological impacts of climate 678 change (Maraun et al. 2010) and, hence, plays an important role for impact-adaptation 679 studies, but is subject to inherent uncertainty. As thermodynamic mechanism (noted earlier in 680 section 5) dominates the future rainfall changes, the well-observed precipitation climatology 681 can be used to constrain future rainfall projection (Huang et al. 2013) and thus partially limits 682 the uncertainty. As one last note to this discussion on regional projection, the current study also suggests that downscaling of the local precipitation changes needs to be performed with 684 only climate models that simulate precipitation variability reasonably well. This strategy, to 685 some extent, may also reduce the burden and uncertainty on the estimation of regional or 686 local precipitation changes in future changes (Joseph and Nigam 2006; Seo and Ok 2013). 
691 Meteorology, India for all the support for this research work. We are also thankful to Drs

692 Krishnan $\mathrm{R}$ and Ramesh $\mathrm{V}$ for their constructive comments on an earlier draft of the 693 manuscript. We also thank three anonymous reviewers for their helpful comments and 694 suggestions. We acknowledge the climate modeling groups, the Program for Climate Model 695 Diagnosis and Intercomparison, and the World Climate Research Programme's working 696 Group on coupled modelling, for their roles in making available the "CMIP5" multi-model 697 data sets, as listed in Table 1. 


\section{References}

699

700

701

702

703

704

705

706

707

708

709

710

711

712

713

714

715

716

717

718

719

720

721

Allen MR, Ingram WJ (2002) Constraints on future changes in climate and the hydrologic cycle. Nature 419:224-232

Annamalai H, Hamilton K, Sperber KR (2007) The South Asian summer monsoon and its relationship with ENSO in the IPCC AR4 simulations. J Clim 20:1071-1092

Annamalai H, Liu P (2005) Response of the Asian Summer Monsoon to changes in El Niño properties. Q J R Meteorol Soc 131:805-831

Ashfaq M, Shi Y, Tung Wm, Trapp RJ, Gao X, Pal JS, Diffenbaugh NS (2009) Suppression of south Asian summer monsoon precipitation in the $21^{\text {st }}$ century. Geophys Res Lett 31 : L01704. doi:10.1029/2008GL036500

Ashrit RG, Kitoh A, Yukimoto S (2005) Transient response of ENSO-monsoon teleconnection in MRI-CGCM2.2 climate change simulations. J Meteorol Soc Jap 83: 273-291

Bayr T, Dommenget D (2013) The Tropospheric Land-Sea Warming Contrast as the Driver of Tropical Sea Level Pressure Changes. J Climate 26: 1387-1402

Bellenger H, Guilyardi E, Leloup J, Lengaigne M, Vialard J (2013) ENSO representation in climate models: from CMIP3 to CMIP5. Clim Dyn. doi 10.1007/s00382-013-1783-z

Bhaskaran B, Mitchell JFB, Lavery JR, Lal M (1995) Climatic response of the Indian subcontinent to doubled $\mathrm{CO}_{2}$ concentration. Int J Climatol 15:873-893

Bollasina M, Ming Y (2013) The general circulation model precipitation bias over the southwestern equatorial Indian Ocean and its implications for simulating the South Asian monsoon. Clim Dyn 40 (3-4). doi:10.1007/s00382-012-1347-7

Cherchi A, Alessandri A, Masina S, Navarra A (2010) Effects of increased $\mathrm{CO}_{2}$ on monsoons. Clim Dyn. doi:10.1007/s00382-010-0801-7 
Chou C, Chen CA (2014) Mechanisms of future precipitation changes. Environ Res Lett (submitted)

Chou C, Neelin JD, Chen CA, Tu JY (2009) Evaluating the "rich-get-richer" mechanism in tropical precipitation change under global warming. J Clim 22:1982-2005

Copsey D, Sutton R, Knight JR (2006) Recent trends in sea level pressure in the Indian Ocean region. Geophy Res Lett 33:L19712. doi:10.1029/2006GL027175

Dai A, Li H, Sun Y, Hong LC, Ho L, Chou C, Zhou T (2013) The relative roles of upper and lower tropospheric thermal contrasts and tropical influences in driving Asian summer monsoons. J Geophys Res 118 : 7024-7045. doi:10.1002/jgrd.50565

Dairaku K, Emori S (2006) Dynamic and thermodynamic influences on intensified daily rainfall during the Asian summer monsoon under doubled atmospheric $\mathrm{CO}_{2}$ conditions. Geophy Res Lett 33:L01704. doi:10.1029/2005GL024754

Douville H (2005) Limitations of time-slice experiments for predicting regional climate change over South Asia. Clim Dyn 24:373-391

Douville H, Chauvin F, Planton S, Royer JF, Salas-Melia D, Tyteca S (2002) Sensitivity of the hydrological cycle to increasing amounts of greenhouse gases and aerosols. Clim Dyn 20:45-68

Douville H, Royer JF, Polcher J, Cox P, Gedney N, Stephenson DB,Valdes PJ (2000) Impact of doubling $\mathrm{CO}_{2}$ on the Asian summer monsoon: robust versus model-dependent responses. J Met Soc Jap 78:421-439

Fan F, Mann ME, Lee S, Evans JL (2010) Observed and modeled changes in the South Asian monsoon over the historical period. J Clim 23:5193-5205

Fan F, Mann ME, Lee S, Evans J (2012) Future changes in the South Asian summer onsoon: An analysis of the CMIP3 multi-model projections. J Clim 25:3909-3928 
Fu C, Fletcher JO (1985) The relationship between Tibet tropical ocean thermal contrast and interannual variability of Indian monsoon rainfall. J Climate Appl Meteorol 24:842-847

Gastineau G, Le Treut H, Li L (2008) Hadley circulation changes under global warming conditions indicated by coupled climate models. Tellus 60A:863-884

Gill AE (1980) Some simple solutions for heat-induced tropical circulation. Q J R Meteorol Soc 106:447-462

He H, Sui CH, Jian M, Wen Z, Lan G (2003) The evolution of tropospheric temperature field and its relationship with the onset of Asian summer monsoon. J Met Soc Jap 81:12011223

Held IM, Soden BJ (2006) Robust responses of the hydrological cycle to global warming. J Clim 19:5686-5699

Holton JR (2004) An Introduction to Dynamic Meteorology. Elsevier Academic Press: Burlington, Mass

Hsu PC, Li T, Luo JJ, Murakami H, Kitoh A, Zhao M (2012) Increase of global monsoon area and precipitation under global warming: a robust signal? Geophys Res Lett 39:L0670. doi:10.1029/2012GL051037

Huang P, Xie SP, Hu K, Huang G, Huang R (2013) Patterns of the seasonal response of tropical rainfall to global warming. Nature Geoscience 6:357-361. doi:10.1038/ngeo1792

Huffman GJ, Adler RF, Bolvin DT, Gu G (2009) Improving the global precipitation record: GPCP Version 2.1. Geophy Res Lett 36: L17808. doi:10.1029/2009GL040000

Joseph PV, Sooraj KP, Rajan CK (2003) Conditions leading to monsoon onset over Kerala and the associated Hadley Cell. Mausam 54:155-164

Joseph R, Nigam S (2006) ENSO evolution and teleconnection in IPCC's twentieth-century climate simulations: Realistic representation? J Clim 19:4360-4377 
Joseph S, Sahai AK, Goswami BN (2010) Boreal summer intraseasonal oscillations and seasonal Indian monsoon prediction in DEMETER coupled models. Clim Dyn 35:651667. doi: 10.1007/s00382-009-0635-3

Jourdain NC, Gupta AS, Taschetto AS, Ummenhofer CC, Moise AF, Ashok K (2013) The Indo-Australian monsoon and its relationship to ENSO and IOD in reanalysis data and the CMIP3/CMIP5 simulations. Clim Dyn doi:10.1007/s00382-013-1676-1

Kalnay EM, Kanamitsu M, Kistler R, Collins W, Deaven D, Gandin L, Iredell M, Saha S, White G, Woollen J, Zhu Y, Leetmaa A, Reynolds R, Chelliah M, Ebisuzaki W, Higgins W, Janowiak J, Mo KC, Ropelewski C, Wang J, Jenne R, Joseph D (1996) The NCEP/NCAR 40-Year Reanalysis Project. Bull Am Met Soc 77:437-471

Kitoh A, Yukimoto S, Noda A, Motoi T (1997) Simulated changes in the Asian summer monsoon at times of increased atmospheric $\mathrm{CO}_{2}$. J Met Soc Jap 75:1019-1031

Kitoh A, Endo H, Krishna Kumar K, Cavalcanti IFA, Goswami P, Zhou T (2013) Monsoons in a changing world: A regional perspective in a global context. J Geophys Res 118: 3053-3065

Knutson TR, Manabe S (1994) Impact of increased $\mathrm{CO}_{2}$ on simulated ENSO-like phenomena. Geophys Res Lett 21:2295-2298

Knutson TR, Manabe S (1995) Time-mean response over the tropical Pacific to increased $\mathrm{CO}_{2}$ in a coupled ocean-atmosphere model. J Clim 8:2181-2199

Knutti R, Sedlacek J (2013) Robustness and uncertainties in the new CMIP5 climate model projections. Nature Clim Change 3:369-373

Kripalani RH, Oh JH, Kulkarni A, Sabade SS, Chaudhari HS (2007) South Asian summer monsoon precipitation variability: coupled model simulations and projections under IPCC AR4. Theor Appl Climatol 90:133-159 
794

795

796

797

798

799

800

801

802

803

804

805

806

807

808

809

810

811

812

813

814

815

816

817

818

Krishna Kumar K, Kamala K, Rajagopalan B, Hoerling MP, Eischeid JK, Patwardhan SK, Srinivasan G, Goswami BN, Nemani R (2010) The once and future pulse of Indian monsoonal climate. Clim Dyn. doi:10.1007/s00382-010-0974-0

Krishnan R, Sabin TP, Ayantika DC, Sugi M, Kitoh A, Murakami H, Turner A, Slingo JM, Rajendran K (2013) Will the South Asian monsoon overturning circulation stabilize any further? Clim Dyn. doi:10.1007/s00382-012-1317-0

Krishnan R, Sundaram S, Swapna P, Kumar V, Ayantika DC, Mujumdar M (2010) The crucial role of ocean-atmosphere coupling on the Indian monsoon anomalous response during dipole events. Clim Dyn. doi:10.1007/s00382-010-0830-2

Lee JY, Wang B (2012) Future change of global monsoon in the CMIP5. Clim Dyn. doi:10.1007/s00382-012-1564-0

Li C, Yanai M (1996) The onset and interannual variability of the Asian summer monsoon in relation to land-sea thermal contrast. J Clim 9:358-375

Li Y, Jourdain NC, Taschetto AS, Ummenhofer CC, Ashok K, Sen Gupta A (2012)

Evaluation of monsoon seasonality and the tropospheric biennial oscillation transitions in the CMIP models. Geophys Res Lett 39:L20713. doi:10.1029/2012GL053322.

Lindzen RS (1990) Some Coolness Concerning Global Warming. Bull Am Met Soc 71:288299

Lu J, Chen G, Frierson DMW (2008) Response of the Zonal Mean Atmospheric Circulation to El Niño versus Global Warming. J Clim 21:5835-5851

Ma J, Yu JY (2014) Paradox in the South Asian summer monsoon circulation change: Lower tropospheric strengthening and upper troposheric weakening. Geophys Res Lett 41. doi: 10.1002/2014GL059891

Maraun D, Wetterhall F, Ireson AM, Chandler RE, Kendon EJ, Widmann M, Brienen S, Rust HW, Sauter J, Themel M, Venema VKC, Chun KP, Goodess CM, Jones RG, Onof 
C, Vrac M, Thiele-Eich I (2010) Precipitation downscaling under climate change: Recent developments to bridge the gap between dynamical models and the end user. Rev Geophys 48. doi 10.1029/2009RG000314

May W (2002) Simulated changes of the Indian summer monsoon under enhanced greenhouse gas conditions in a global time-slice experiment. Geophys Res Lett 29. doi:10.1029/2001GL013808

May W (2004) Simulation of the variability and extremes of daily rainfall during the Indian summer monsoon for present and future times in a global time-slice experiment. Clim Dyn 22:183-204

May W (2010) The sensitivity of the Indian summer monsoon to a global warming of $2{ }^{\circ} \mathrm{C}$ with respect to pre-industrial times. Clim Dyn. doi:10.1007/s00382-010-0942-8

Meehl GA, Arblaster JM (2003) Mechanisms for projected future changes in South Asian monsoon precipitation. Clim Dyn 21:659-675

Meehl GA, Washington WM (1993) South Asian summer monsoon variability in a model with a doubled atmospheric carbon-dioxide concentration. Science 260:1101-1104

Menon A, Levermann A, Schewe J, Lehmann J, Frieler K (2013) Consistent increase in Indian monsoon rainfall and its variability across CMIP-5 models. Earth Syst Dynam Discuss 4: 1-24. doi:10.5194/esdd-4-1-2013

Neelin J D, Chou C, Su H (2003) Tropical drought regions in global warming and El Niño Teleconnections. Geophys Res Lett 30:2275. doi:10.1029/2003GL018625.

Ogata T, Ueda H, Inoue T, Hayasaki M, Yoshida A, Watanabe S, Kira M, Ooshiro M, Kumai A (2014) Projected Future Changes of the Asian Monsoon: A Comparison of CMIP3 and CMIP5 model results. J Meterol soc Japan 92 (in press) 
Prodhomme C, Terray P, Masson S, Izumo T, Tozuka T, Yamagata T (2014a) Impacts of Indian Ocean SST biases on the Indian Monsoon: as simulated in a global coupled model. Clim Dyn 42: 271-290. doi:10.1007/s00382-013-1671-6

Prodhomme C, Terray P, Masson S, Boschat G, Izumo T (2014b) Oceanic factors controlling the Indian Summer Monsoon onset in a coupled model. Clim Dyn (in press)

Sabin TP, Krishnan R, Ghattas J, Denvil S, Dufresne JL, Hourdin F, Pascal T (2013) High resolution simulation of the South Asian monsoon using a variable resolution global climate model. Clim Dyn 41:173-194

Santer BD, Thorne PW, Haimberger L, Taylor KE, Wigley TML, Lanzante JR, Solomon S, Free M, Gleckler PJ, Jones PD, Karl TR, Klein SA, Mears C, Nychka D, Schmidt GA, Sherwood SC, Wentz FJ (2008) Consistency of modelled and observed temperature trends in the tropical troposphere. Intl J Climatol 28:1703-1722. doi:10.1002/joc.1756.

Seidel DJ, Randel WJ (2007) Recent widening of the tropical belt: Evidence from tropopause observations. J Geophys Res 112. D20113. doi:10.1029/2007JD008861

Seidel DJ, Fu Q, Randel WJ, Reichler T (2008) Widening of the tropical belt in a changing climate. Nature Geosci 1:21-24

Seo KH, Ok J (2013) Assessing future changes in the East Asian summer monsoon using CMIP3 models: Results from the best model ensemble. J Clim 26:1807-1817

Sobel A, Held I, Bretherton C (2002) The ENSO signal in tropical tropospheric temperature. J Clim 15:2702-2706.

Sperber KR, Annamalai H, Kang IS, Kitoh A, Moise A, Turner AG, Wang B, Zhou T (2013) The Asian summer monsoon: An intercomparison of CMIP5 vs. CMIP3 simulations of the late $20^{\text {th }}$ century. Clim Dyn. doi:10.1007/s00382-012-1607-6.

Stephenson DB, Douville H, Rupa Kumar K (2001) Searching for a fingerprint of global warming in the Asian summer monsoon. Mausum 52:213-220 
Stowasser M, Annamalai H, Hafner J (2009) Response of the South Asian summer monsoon to global warming: mean and synoptic systems. J Clim 22:1014-1036

Su H, Neelin JD (2002) Teleconnection mechanisms for tropical Pacific descent anomalies during El Niño. J Atmos Sci 59: 2694-2712

Sutton RT, Dong B, Gregory JM (2007) Land/sea warming ratio in response to climate change: IPCC AR4 model results and comparison with observations. Geophys Res Lett 34:L02701. doi:10.1029/2006GL028164.

Taylor KE (2001) Summarizing multiple aspects of model performance in a single diagram. J Geophys Res 106(D7):7183-7192

Taylor KE, Stouffer RJ, Meehl GA (2012) An overview of CMIP5 and the experiment design. Bull Am Meteor Soc 93:485-498

Turner AG, Annamalai H (2012) Climate change and the South Asian summer monsoon. Nature Clim Change. doi:10.1038/NCLIMATE1495.

Turner AG, Slingo JM (2009) Uncertainties in future projections of extreme precipitation in the Indian monsoon region. Atmos Sci Lett 10:152-168. doi:10.1002/asl.223

Turner AG, Inness PM, Slingo JM (2007) The effect of doubled $\mathrm{CO}_{2}$ and model basic state biases on the monsoon-ENSO system. I: mean response and interannual variability. Quart J R Meteorol Soc 133:1143-1157

Ueda H, Iwai A, Kuwako K, Hori ME (2006) Impact of anthropogenic forcing on the Asian summer monsoon as simulated by eight GCMs. Geophys Res Lett 33:L06703. doi:10.1029/2005GL025336

Veechi GA, Soden BJ (2007) Global warming and the weakening of the tropical circulation. J Clim 20:4316-4340 
890

891

892

893

894

895

896

897

898

899

900

901

902

903

904

905

906

907

908

909

910

911

Veechi GA, Soden BJ, Wittenberg AT, Held IM, Leetma A, Harrison MJ (2006) Weakening of tropical Pacific atmospheric circulation due to anthropogenic forcing. Nature $441: 73-76$

Wang B, Fan Z (1999) Choice of south Asian summer monsoon indices. Bull Am Met Soc $80: 629-638$

Webster PJ, Magaña VO, Palmer TN, Shukla J, Tomas RA, Yanai M, Yasunari T (1998) Monsoons: Processes, predictability, and the prospects for prediction. J Geophys Res $103: 14451-14510$

Wu Z, Sarachik ES, Battisti DS (2001) Thermally driven tropical circulations under Raleigh friction and Newtonian cooling/analytic solutions. J Atmos Sci 58:724-741

Xavier PK, Marzin C, Goswami BN (2007) An objective definition of the Indian summer monsoon season and a new perspective on the ENSO-monsoon relationship. Quart J R Meteorol Soc 133:749-764

Xu K, Emanuel KA (1989) Is the tropical atmosphere conditionally unstable? Mon Wea Rev $117: 1471-1479$

Yanai M, Li C (1994) Mechanism of Heating and the boundary layer over the Tibetan Plateau. Mon Wea Rev 122:305-323

Yeh SW, Ham YG, Lee JY (2012) Changes in the tropical Pacific SST trend from CMIP3 to CMIP5 and its implication of ENSO. J Clim 25:7764-7771 


\section{Figure Captions}

Figure 1. Taylor diagram analysis using JJAS mean rainfall $\left(\mathrm{mm} \mathrm{day}^{-1}\right)$ over ASM region $\left(30^{\circ} \mathrm{E}-120^{\circ} \mathrm{E}\right.$ and $\left.30^{\circ} \mathrm{S}-30^{\circ} \mathrm{N}\right)$ during the present-day period of $1980-1999$ for $19 \mathrm{CMIP} 5$ coupled models. In (a) climatological mean and (b) interannual standard deviation.

Figure 2. Mean patterns in rainfall $\left(\mathrm{mm} \mathrm{day}^{-1}\right)$ and $850 \mathrm{hPa}$ wind $\left(\mathrm{m} \mathrm{s}^{-1}\right)$ for JJAS period. In (a) ensemble mean (ENS average for 7 good models) and (b) GPCP rainfall. In (d) ensemble mean wind and (e) same as (d), but for NCEP reanalysis. (c) and (f), show the ensemble mean model bias relative to GPCP and NCEP, respectively. Shadings in (d), (e) and (f) represent the zonal wind flow. In $(\mathrm{g})$, seasonal cycle of rainfall $\left(\mathrm{mm} \mathrm{day}^{-1}\right)$ over Indian monsoon region $\left(10^{\circ} \mathrm{N}-25^{\circ} \mathrm{N}, 60^{\circ} \mathrm{E}-100^{\circ} \mathrm{E}\right)$ for 7 good models (see text for more details) and observation.

Figure 3: Ensemble mean (ENS) patterns in (a) surface temperature $\left({ }^{\circ} \mathrm{C}\right)$ and (c) sea level pressure $(\mathrm{hPa})$, for JJAS period. (b) and (d) show, respectively, the model temperature and SLP biases relative to NCEP reanalysis.

Figure 4: Future change patterns in ensemble mean for 7 good models (ENS). In (a) surface temperature $\left({ }^{\circ} \mathrm{C}\right)$ and (b) sea level pressure $(\mathrm{hPa})$, for JJAS period. Please see the text (see section 2.2) for more details. Shadings represent the significant changes at the $90 \%$ confidence level. (c) is same as (b) but for ensemble mean made using 15 models (ENS15) listed in Table 1. See text more details.

Figure 5: Future change patterns in ensemble mean (ENS). In (a) precipitation ( $\mathrm{mm} \mathrm{day}^{-1}$ ), (b) wind at $850 \mathrm{hPa}\left(\mathrm{m} \mathrm{s}^{-1}\right)$ and (c) wind at $200 \mathrm{hPa}\left(\mathrm{m} \mathrm{s}^{-1}\right)$, for JJAS period. Shadings in panel (a) represent the significant rainfall changes at $90 \%$ confidence level and zero contours are highlighted in black colour. Shadings in (b) and (c) are the significant zonal wind at $90 \%$ confidence level. In (d), future change in zonal vertical wind shear averaged along a latitudinal band of Equator $-10^{\circ} \mathrm{N}$, as observed across the good models. Shear is defined as difference in zonal wind at $850 \mathrm{hPa}$ and $200 \mathrm{hPa}$ levels. In (e) and (f), same as that of (a) and (b), respectively, but for ENS15. ENS15 refers to model ensemble mean using 15 models listed in Table 1. See text for more details.

Figure 6: (a) Future change in zonal vertical wind shear averaged along a latitudinal band of Equator- $20^{\circ} \mathrm{N}$, as observed across the good models. Shear is defined as difference in zonal wind at $850 \mathrm{hPa}$ and $200 \mathrm{hPa}$ levels. In (b), same as that of (a), but for vertical velocity $\left(\times-10^{2} \mathrm{~Pa} \mathrm{~s}^{-1}\right)$ at $500 \mathrm{hPa}$ averaged along a latitudinal band of $10^{\circ} \mathrm{S}-10^{\circ} \mathrm{N}$ in the Indo-Pacific region. (c) is same as that of (b), but averaged along $60^{\circ}-100^{\circ} \mathrm{E}$. We have also included the ENS and ENS15 averages in all the panels. See the figure caption of Figure 5 for details on ENS and ENS15.

Figure 7: (a) Present-day pattern in ensemble mean (ENS) TT. See text for a detailed definition of TT (upper tropospheric Temperature, ${ }^{\circ} \mathrm{K}$ ). In (b), future change patterns (in contours) in ENS TT. In (b), shadings represent significant TT at $90 \%$ confidence level. In (c), vertical profile of temperature changes $\left({ }^{\circ} \mathrm{C}\right)$ averaged over the domain $\left(50^{\circ}-100^{\circ} \mathrm{E}, 30^{\circ}\right.$ $\left.45^{\circ} \mathrm{N}\right)$ is plotted across the models. In (d), same as (c), but over the domain $\left(50^{\circ}-100^{\circ} \mathrm{E}, 15^{\circ} \mathrm{S}-\right.$ 
$\left.95110^{\circ} \mathrm{N}\right)$. Vertical axis is in hPa units. We have also included the ENS15 average in panels (c)

952 and (d). Please see the figure caption of Figure 5 for the details on ENS15.

953 Figure 8 (a) to (b): Vertical profile of potential temperature changes $\left({ }^{\circ} \mathrm{K}\right)$, averaged over two 954 domains, is plotted across good models. In (a), the domains are bounded by $50^{\circ}-110^{\circ} \mathrm{E}$, Eq$95530^{\circ} \mathrm{N}$, while (b) is bounded by $30^{\circ}-120^{\circ} \mathrm{E}, 30^{\circ} \mathrm{S}-30^{\circ} \mathrm{N}$. Vertical axis is in hPa units.

956 Figure 9 a-d: Decomposition of future rainfall change in the ENS average as determined from 957 the water vapour budget equation (1), see text for more details. (a) rainfall (in mm day ${ }^{-1}$ ) 958 change, (b) dynamic component $(\Delta \omega \cdot \bar{q})$ and (c) thermodynamic component $(\bar{\omega} \cdot \Delta q)$. (d) is 959 (b) + (c). Unit for (b), (c) and (d) is in $10^{-5} \mathrm{~Pa} \mathrm{~s}^{-1}$. In all the panels, zero contours are 960 highlighted in black colour. Note here that equation (1) implicitly assumes that the upward 961 velocity is positive.

962 Figure 10: Vertical profile of vertical pressure velocity changes $\left(\times-10^{2} \mathrm{~Pa} \mathrm{~s}^{-1}\right)$, averaged over 963 the region in (a) over $70^{\circ} \mathrm{E}-100^{\circ} \mathrm{E}$, Equator $-20^{\circ} \mathrm{N}$ and in (b) over $70^{\circ} \mathrm{E}-100^{\circ} \mathrm{E}, 10^{\circ} \mathrm{S}$-Equator. 964 (c) and (d), same as that of (a) and (b), but for specific humidity $\left(\times 10^{3} \mathrm{Kg} \mathrm{Kg}^{-1}\right)$. Vertical 965 axis is in $\mathrm{hPa}$ units. 
(a) climatological mean for JJAS

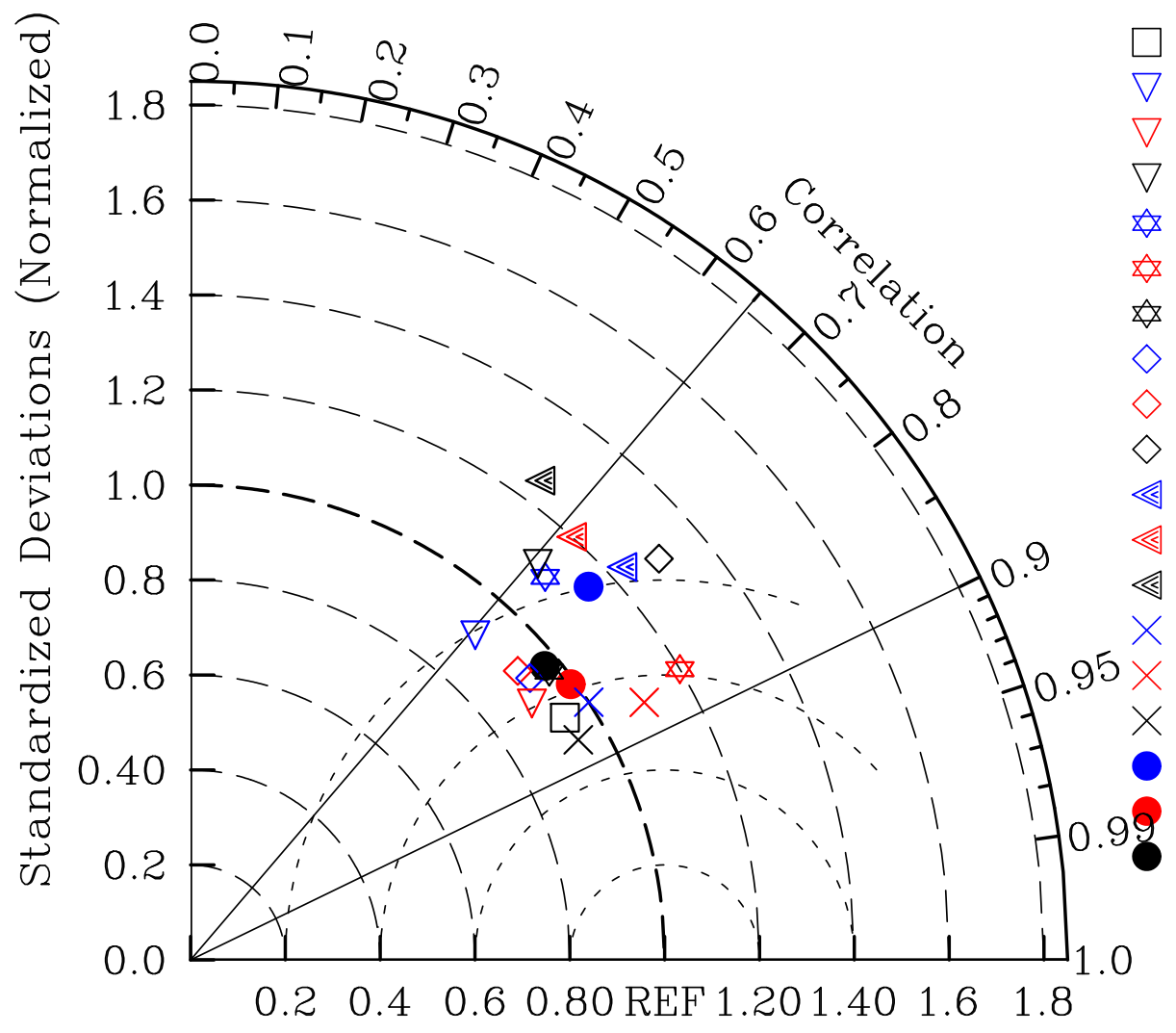

(b) standard deviation for JJAS

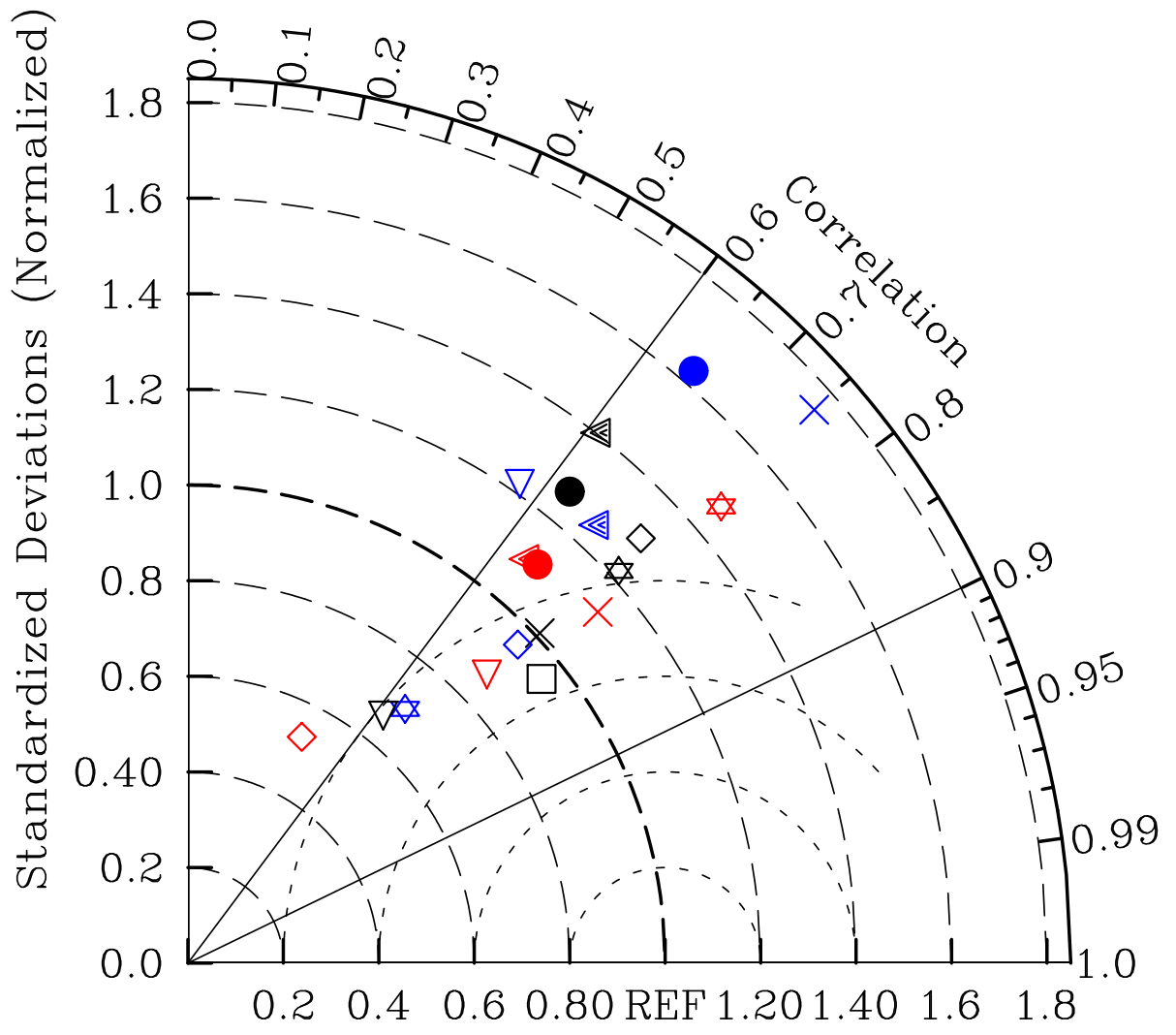

\author{
NorESM1-M \\ MRI-CGCM3 \\ CNRM-CM5 \\ MIROC-ESM \\ MIROC-CHEM \\ MIROC5 \\ IPSL-MR \\ IPSL-LR \\ INMcm 4 \\ HadGEM2-ES \\ HadGEM2-CC \\ GISS-E2-R \\ GISS-E2-H \\ GFDL-ESM2M \\ GFDL-ESM2G \\ GFDLCM3 \\ CSIRO \\ CCSM4 \\ BCC-csm
}


(a)

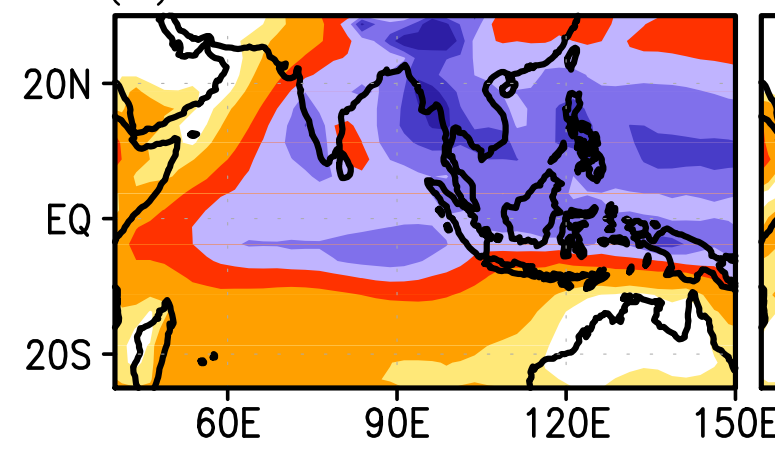

(b)

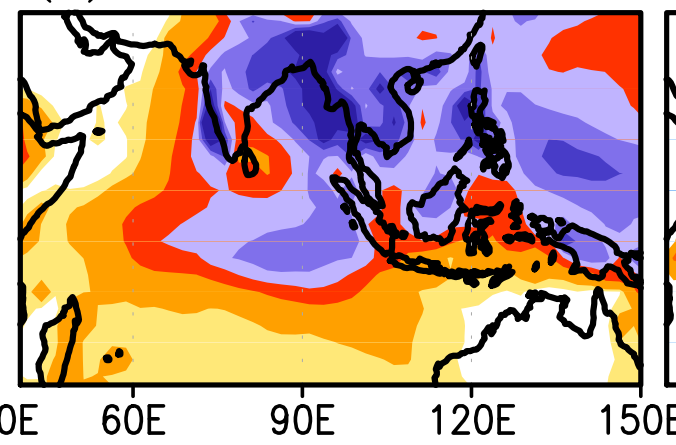

(c)

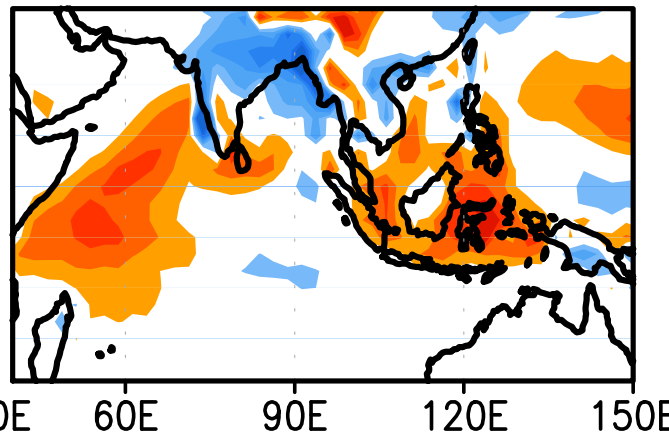

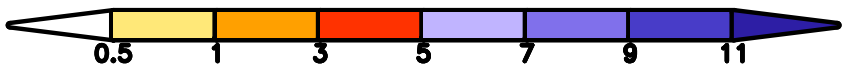

(d)

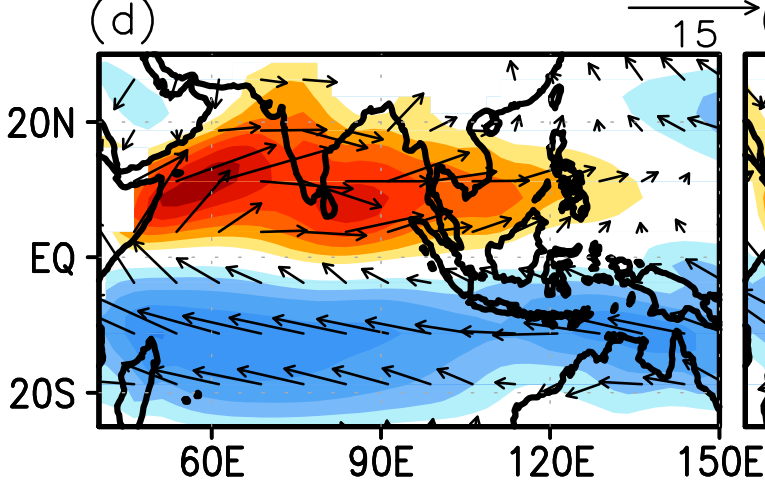

$(\mathrm{e})$

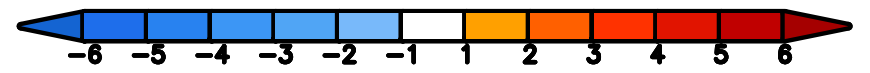

(f)
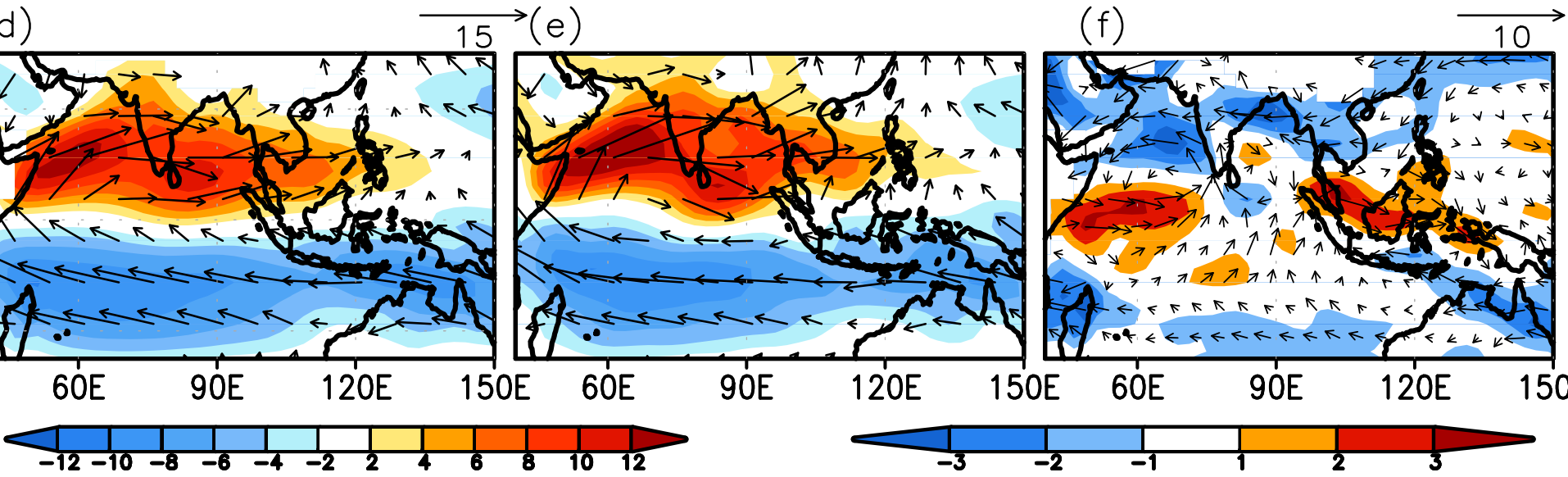

90E 120E 150E

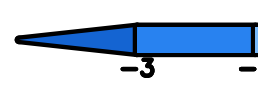

$60 \mathrm{E}$

90E

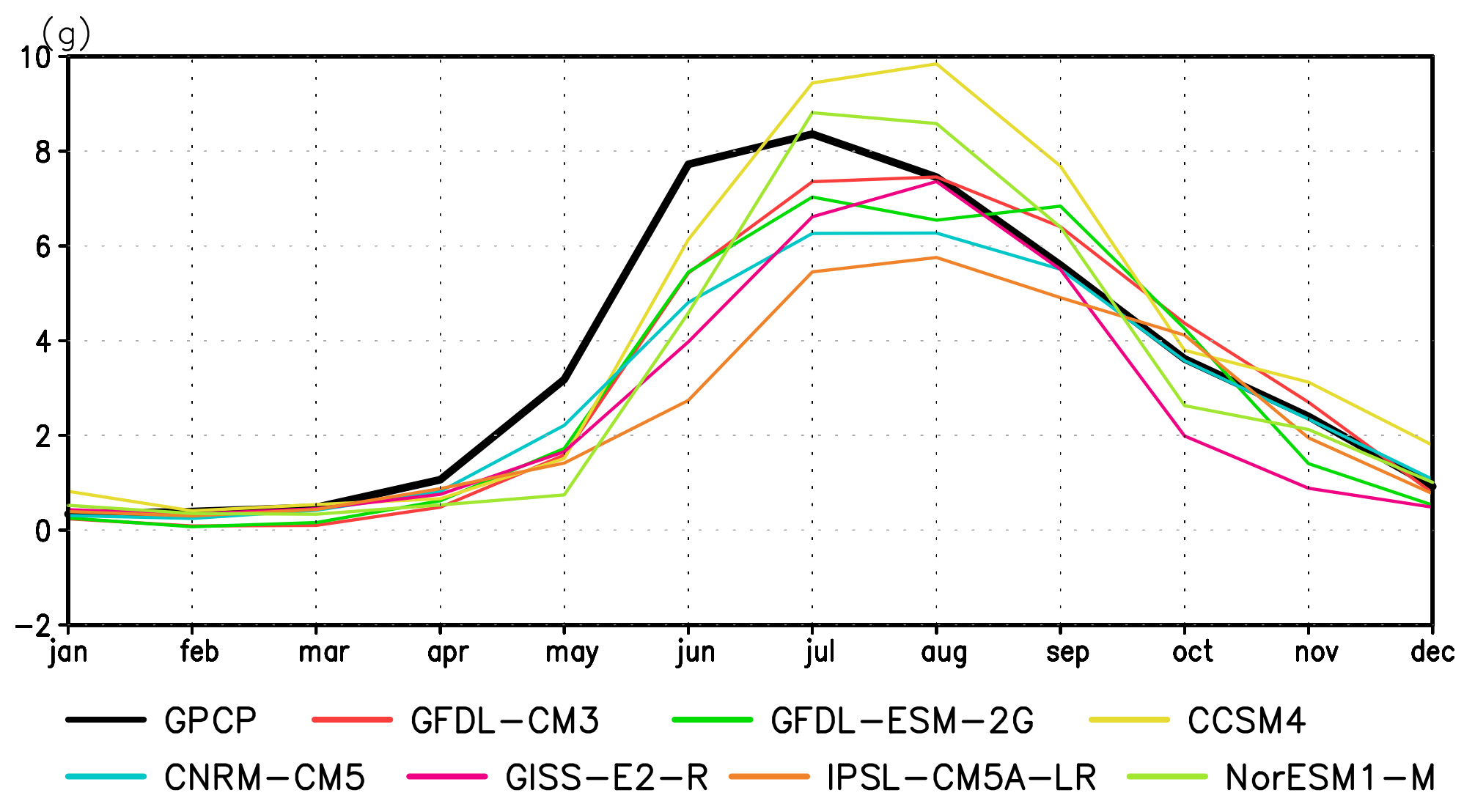



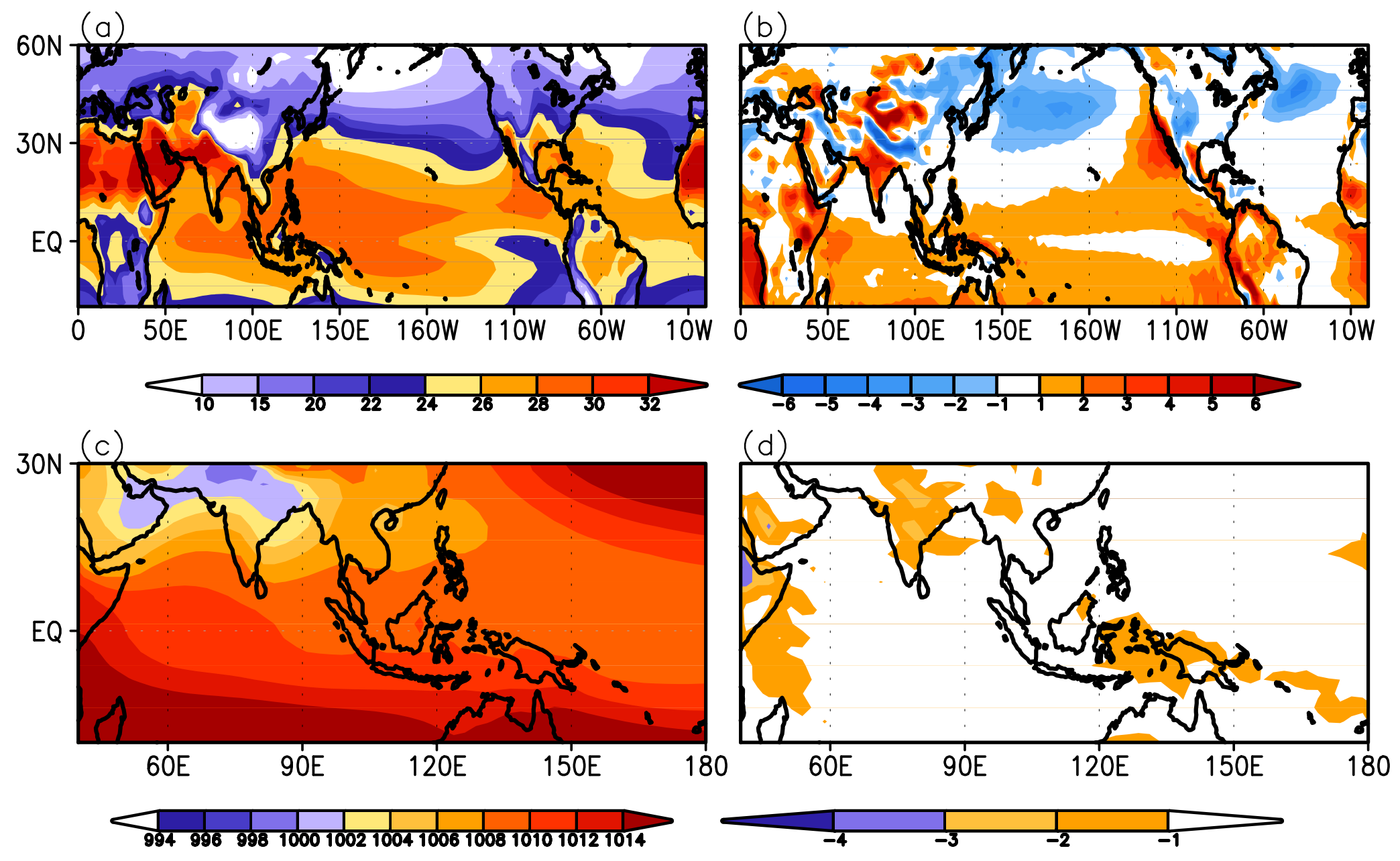


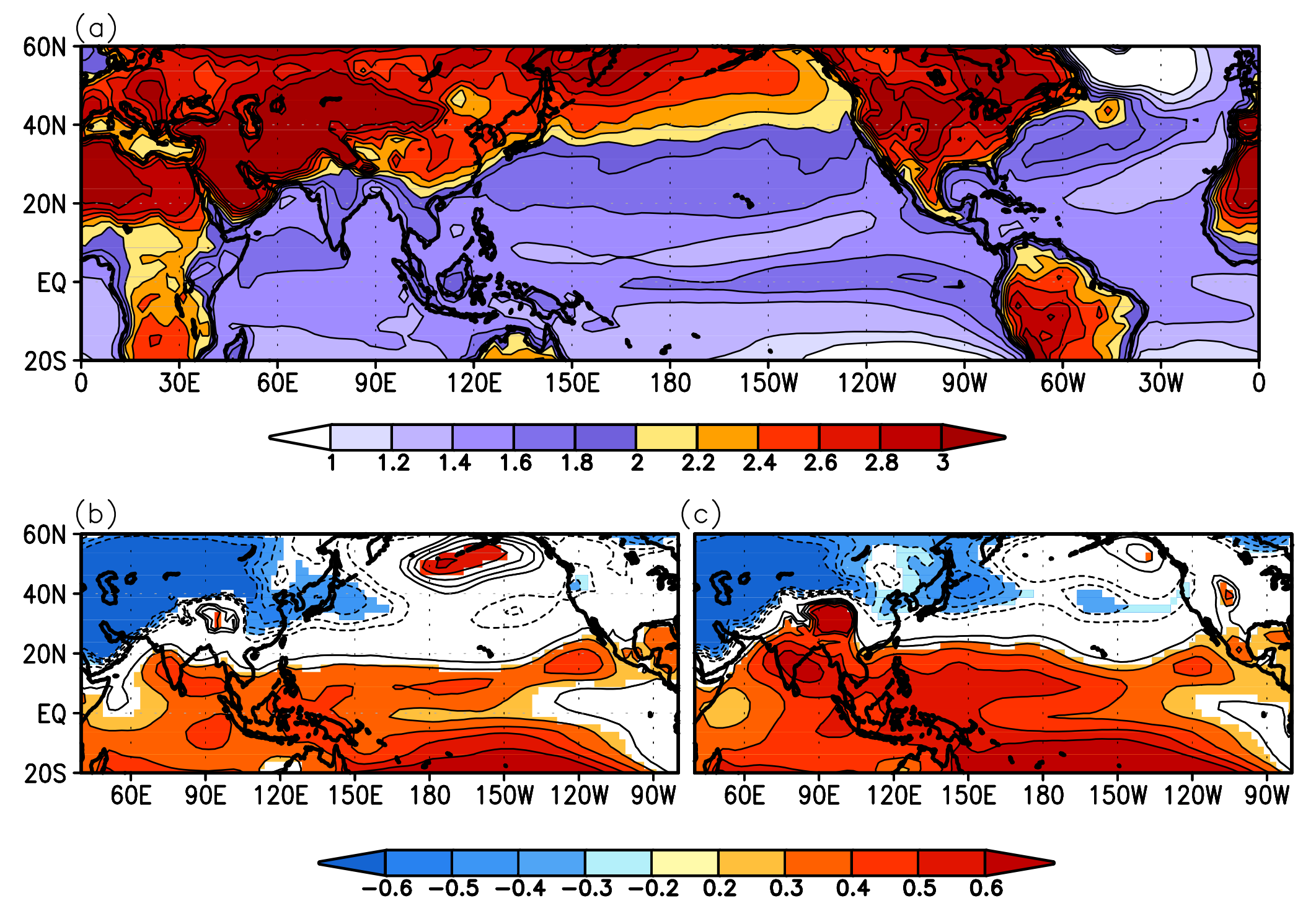


(a)

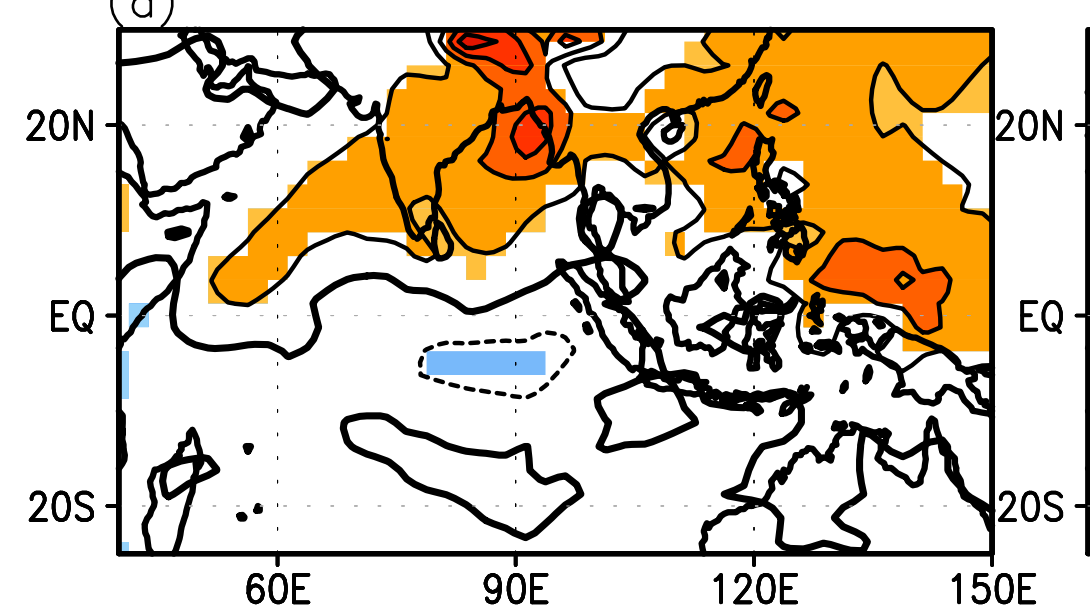

(b)

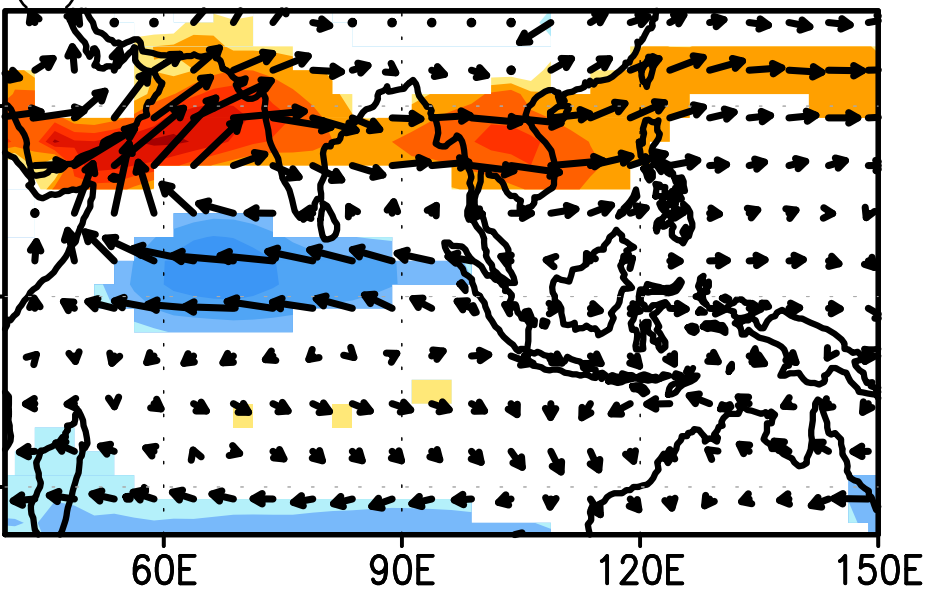

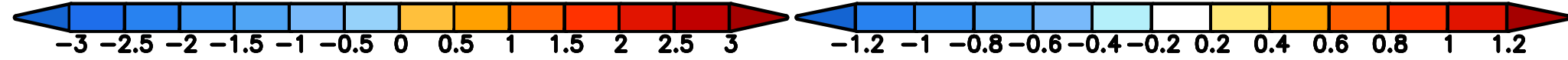

(c)

$23(d)$

$20 \mathrm{~N}$

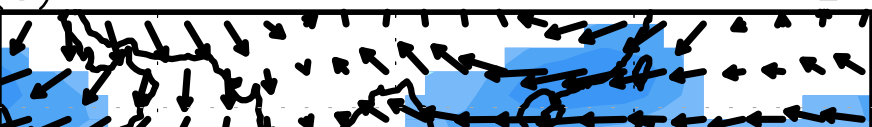

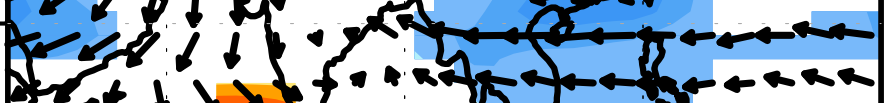

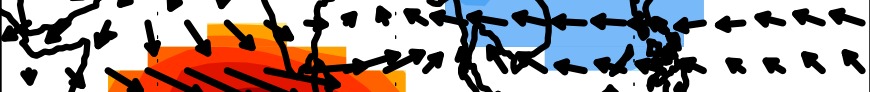

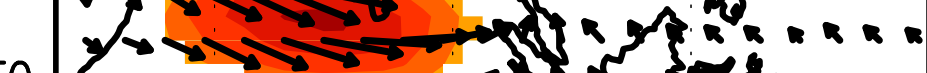

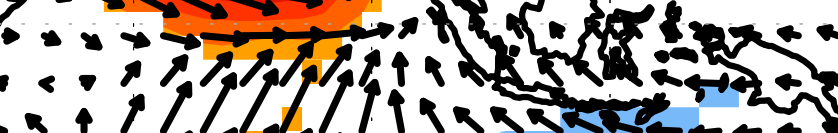

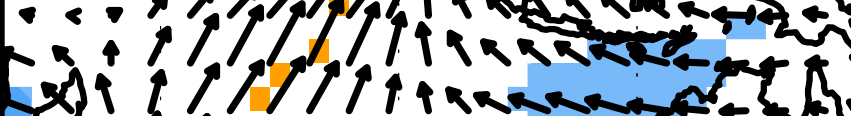

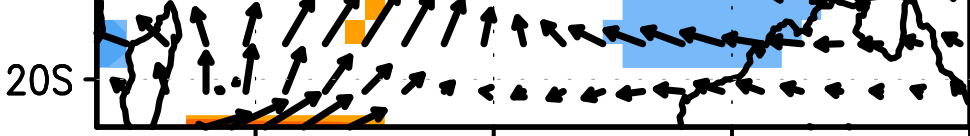
$60 \mathrm{E}$

$120 \mathrm{E}$ $150 \mathrm{E}$

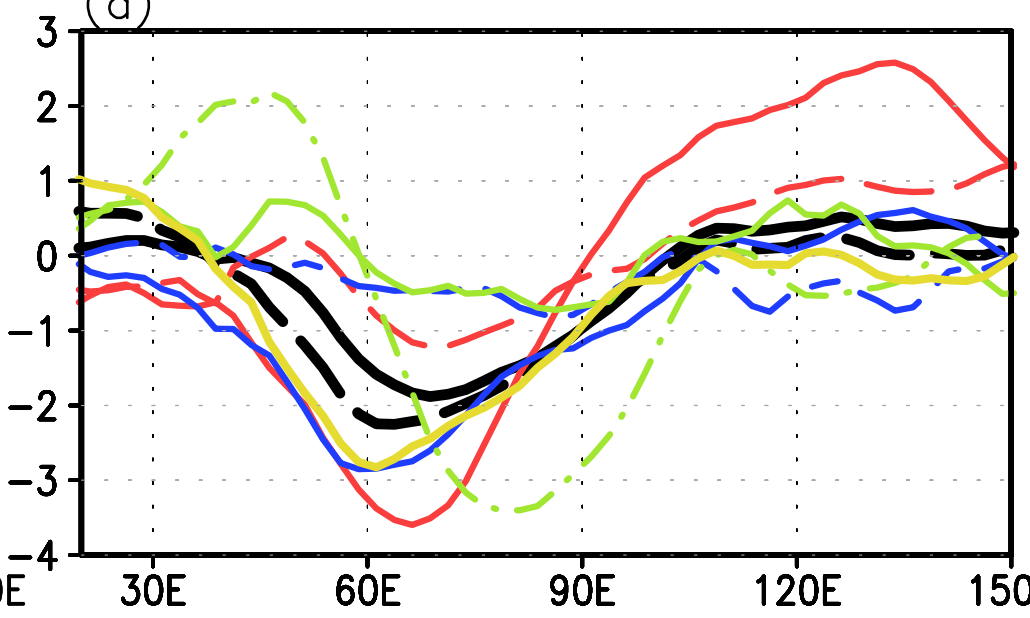

(e)

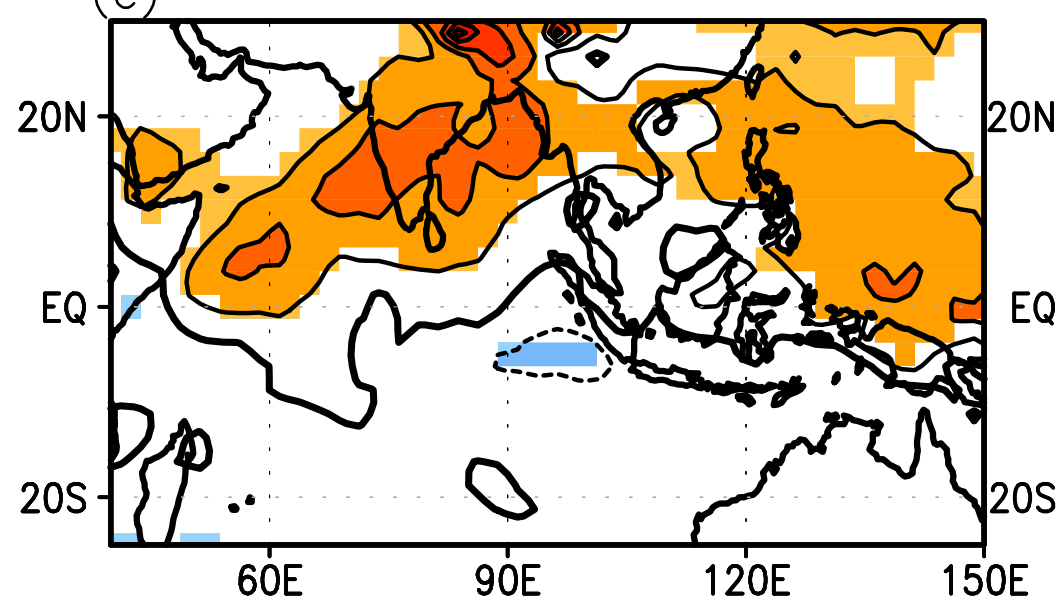

(f)

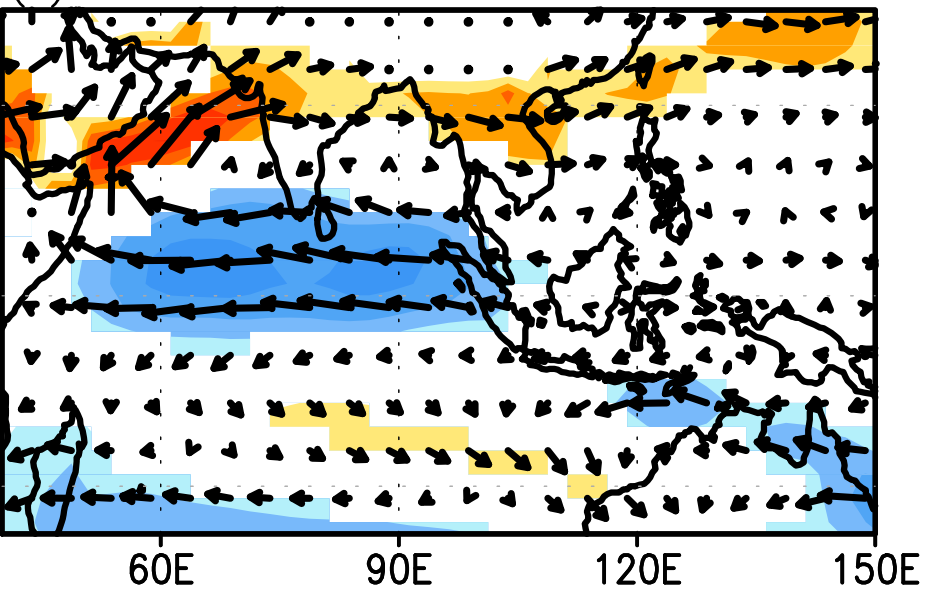

- ENS - ENS15 GFDL-CM3

- GFDL-ESM-2G $\operatorname{CCSM} 4$

- CNRM-CM5 GISS-E2-R IPSL-CM5A-LR NorESM 1-M 
Fig6: Future change in vertical wind shear and vertical velocity

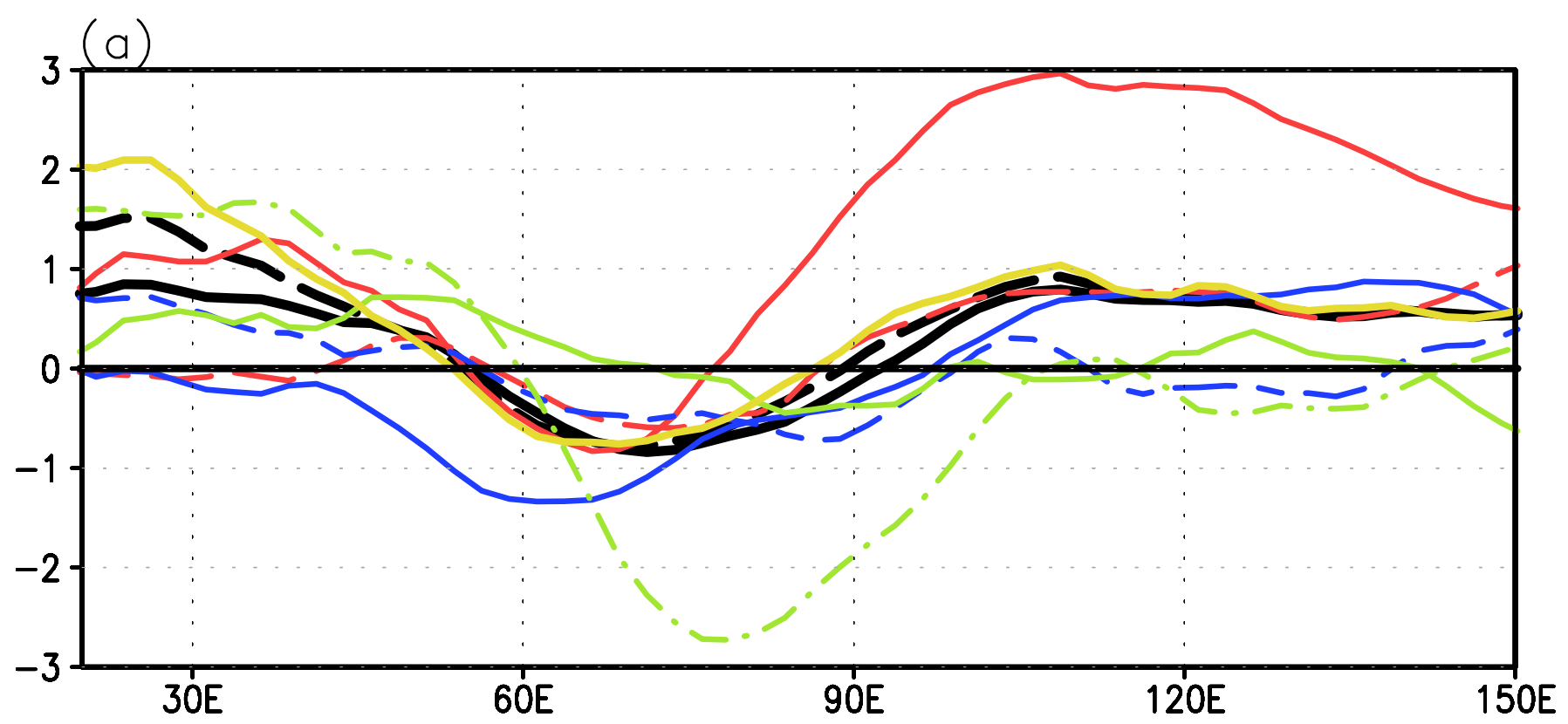

(b)
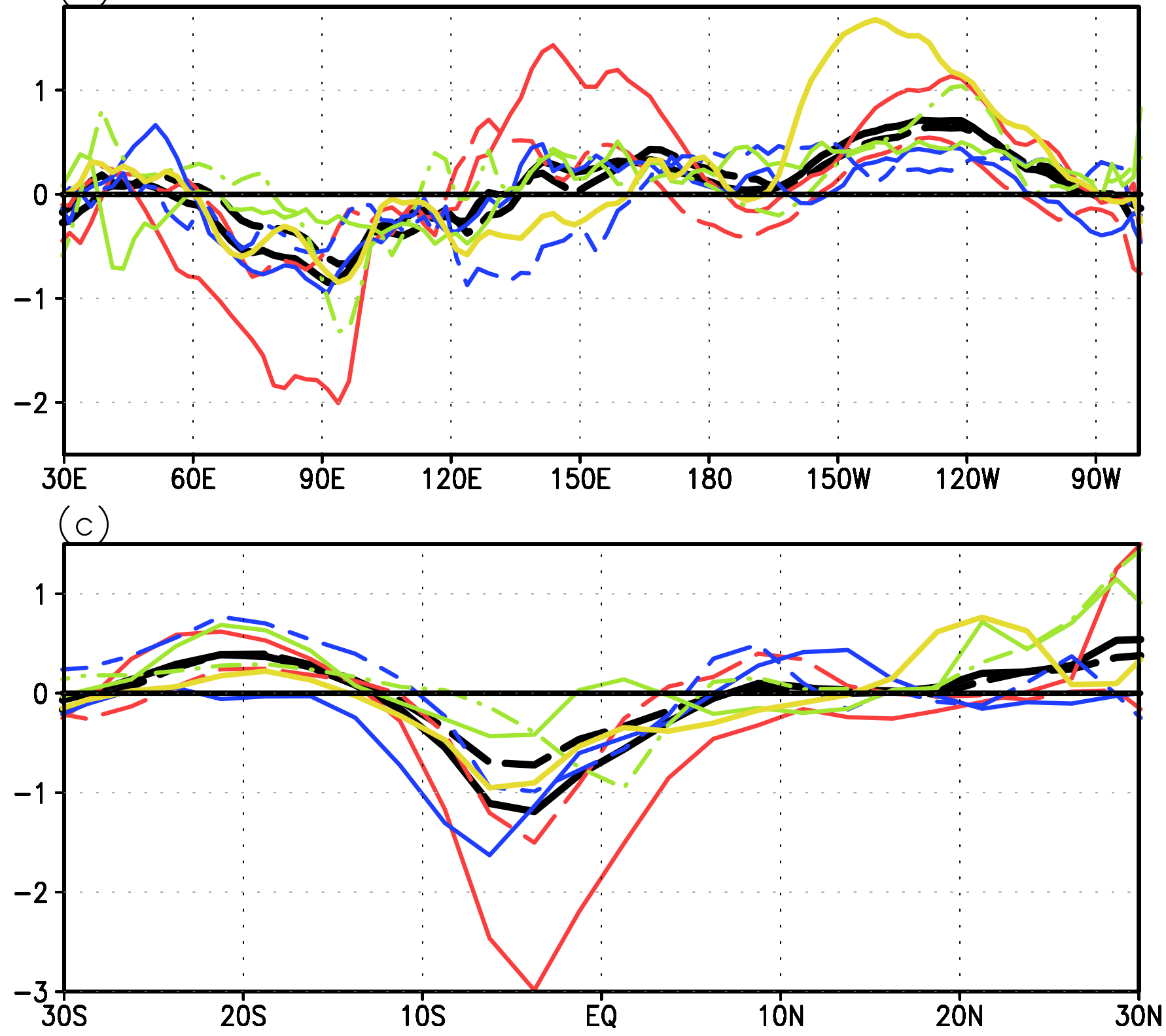

ENS - ENS15 - GFDL-CM3 - GFDL-ESM-2G $\operatorname{CCSM} 4$ - CNRM-CM5 - GISS-E2-R - - IPSL-CM5A-LR - NorESM1-M 

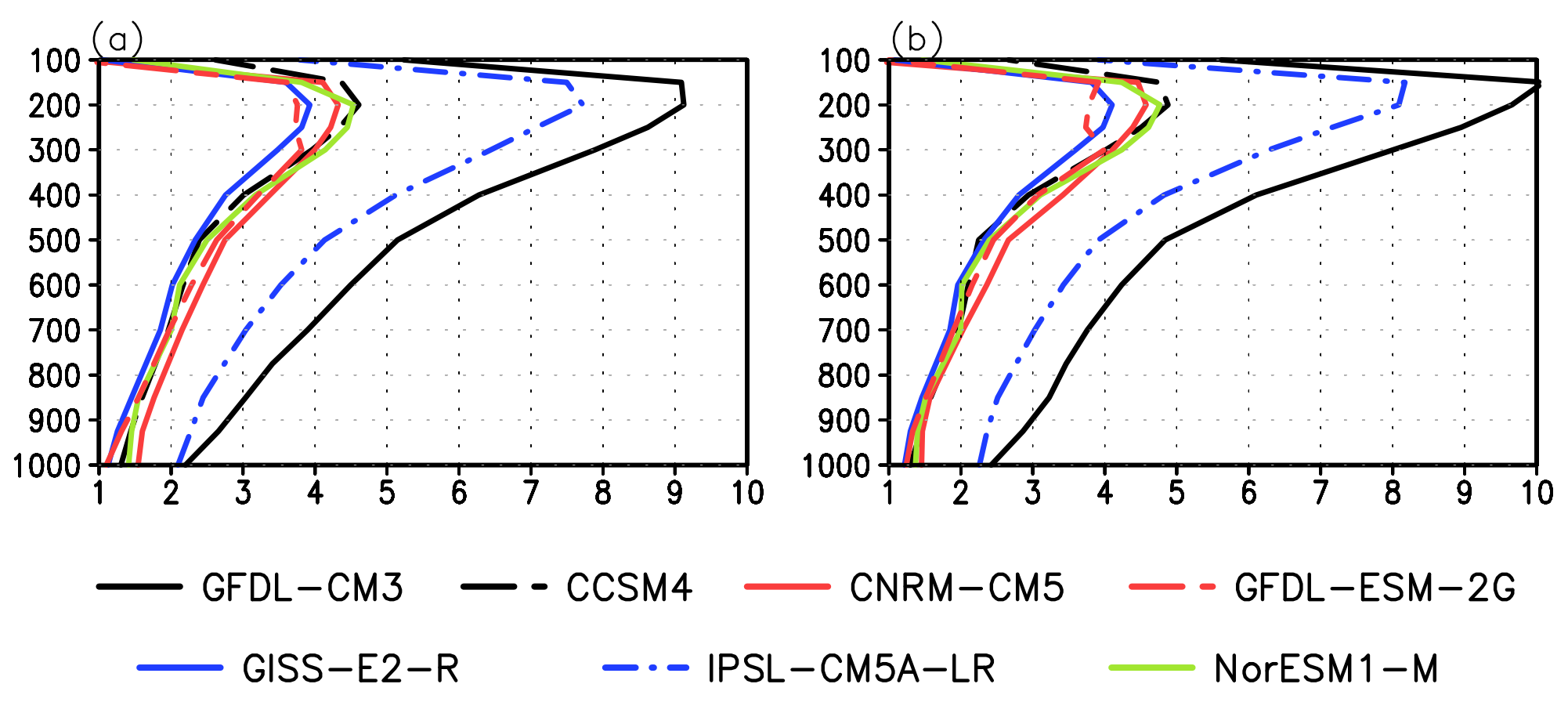
Table 1: Description of CMIP5 models used in our analysis. The models indicated in bold face are the selected good models derived using Taylor diagrams (see section 2.2.1).

\begin{tabular}{|c|c|c|c|}
\hline No. & $\begin{array}{l}\text { Couple model } \\
\text { name }\end{array}$ & Institution & $\begin{array}{l}\text { Resolution } \\
\text { (Lon } \times \text { Lat Le- } \\
\text { vels) }\end{array}$ \\
\hline 1 & BCC-CSM1.1 & $\begin{array}{l}\text { Beijing Climate Center, China Meteorological } \\
\text { Administration }\end{array}$ & $128 \times 64$ L26 \\
\hline 2 & CCSM4 & National Center for Atmospheric Research & $288 \times 192$ L26 \\
\hline 3 & CNRM-CM5 & $\begin{array}{l}\text { Centre National de Recherches Meteorologiques / } \\
\text { Centre Europeen de Recherche et Formation } \\
\text { Avancees en Calcul Scientifique }\end{array}$ & $256 \times 128$ L31 \\
\hline 4 & CSIRO-Mk3.6.0 & $\begin{array}{l}\text { Commonwealth Scientific and Industrial Research } \\
\text { Organisation in collaboration with the Queensland } \\
\text { Climate Change Centre of Excellence }\end{array}$ & $192 \times 96$ L18 \\
\hline 5 & GFDL-CM3 & Geophysical Fluid Dynamics Laboratory & $144 \times 90 \mathrm{L48}$ \\
\hline 6 & GFDL-ESM-2G & Geophysical Fluid Dynamics Laboratory & $144 \times 90 \mathrm{~L} 24$ \\
\hline 7 & GFDL-ESM-2M & Geophysical Fluid Dynamics Laboratory & $144 \times 90$ L24 \\
\hline 8 & GISS-E2-H & NASA Goddard Institute for Space Studies & $144 \times 90$ L40 \\
\hline 9 & GISS-E2-R & NASA Goddard Institute for Space Studies & $144 \times 90$ L40 \\
\hline 10 & HadGEM2-CC & Met Office Hadley Centre & $192 \times 145 \mathrm{~L} 40$ \\
\hline 11 & HadGEM2-ES & Met Office Hadley Centre & $192 \times 145$ L40 \\
\hline 12 & INM-CM4 & Institute for Numerical Mathematics & $180 \times 120 \mathrm{~L} 21$ \\
\hline 13 & IPSL-CM5A-LR & Institut Pierre-Simon Laplace & $96 \times 96$ L39 \\
\hline 14 & IPSL-CM5A-MR & Institut Pierre-Simon Laplace & $144 \times 143$ L39 \\
\hline 15 & MIROC5 & $\begin{array}{l}\text { Atmosphere and Ocean Research Institute (The } \\
\text { University of Tokyo), National Institute for } \\
\text { Environmental Studies, and Japan Agency for Marine- } \\
\text { Earth Science and Technology }\end{array}$ & $256 \times 128 \mathrm{~L} 40$ \\
\hline 16 & MIROC-ESM & $\begin{array}{l}\text { Japan Agency for Marine-Earth Science and Technology, } \\
\text { Atmosphere and Ocean Research Institute (The } \\
\text { University of Tokyo), and National Institute for } \\
\text { Environmental Studies }\end{array}$ & $128 \times 64 \mathrm{~L} 80$ \\
\hline 17 & $\begin{array}{l}\text { MIROC-ESM- } \\
\text { CHEM }\end{array}$ & $\begin{array}{l}\text { Japan Agency for Marine-Earth Science and Technology, } \\
\text { Atmosphere and Ocean Research Institute (The } \\
\text { University of Tokyo), and National Institute for } \\
\text { Environmental Studies }\end{array}$ & $128 \times 64 \mathrm{~L} 80$ \\
\hline 18 & MRI-CGCM3 & Meteorological Research Institute & $320 \times 160$ L48 \\
\hline 19 & NorESM1-M & Norwegian Climate Centre & $144 \times 96$ L26 \\
\hline
\end{tabular}


Table 2: Variables related to future change in ASM. (a) Present-day climate from historical simulations and (b) Future change. Here surface temperature (Surf. Tmp.), rain rate (Pave), Evap (evaporation rate) and CWC (total column integrated water vapor content) are averaged over the north ASM region $\left(50^{\circ}-110^{\circ} \mathrm{E}, \mathrm{Eq}-30^{\circ} \mathrm{N}\right)$. Zonal wind index (U) at $850 \mathrm{hPa}$ is defined over $60^{\circ}-100^{\circ} \mathrm{E}$, Eq$10^{\circ} \mathrm{N}$. Monsoon Hadley Cell (MHC) strength is defined as $\mathrm{V}_{850^{\circ}}-\mathrm{V}_{200}\left(850-\mathrm{hPa} \mathrm{V}\right.$ wind over $40^{\circ}-55^{\circ} \mathrm{E}$, $10^{\circ} \mathrm{S}-10^{\circ} \mathrm{N}$ and $200-\mathrm{hPa} \mathrm{V}$ wind over $\left.45^{\circ}-75^{\circ} \mathrm{E}, 20^{\circ} \mathrm{S}-\mathrm{Eq}\right)$. V represents the meridional wind. Note that here the future change (defined as the difference between the 2080-2099 period in RCP 4.5 and the 1980-1999 historical period) is expressed in percentage, relative to the mean during the period 1980 to 1999 of the historical simulation.

(a) Present-day climate from historical simulation

\begin{tabular}{|l|c|c|c|c|c|c|c|}
\hline Models & $\begin{array}{c}\text { Surf. Tmp. } \\
\left({ }^{0} \mathbf{C}\right)\end{array}$ & $\begin{array}{c}\text { Pave } \\
\left(\mathbf{m m ~ d a y}^{-1}\right)\end{array}$ & $\begin{array}{c}\text { Evap. } \\
\left(\mathbf{m m} \mathbf{d a y}^{-1}\right)\end{array}$ & $\begin{array}{c}\mathbf{C W C} \\
\left(\mathbf{k g ~ m}^{-2}\right)\end{array}$ & $\begin{array}{c}\text { Atmo. } \\
\text { Stab. } \\
\left({ }^{0} \mathbf{K}\right)\end{array}$ & $\begin{array}{c}\mathbf{U} \\
\left(\mathbf{m ~ s}^{-1}\right)\end{array}$ & $\begin{array}{c}\text { MHC } \\
\left(\mathbf{m ~ s}^{-1}\right)\end{array}$ \\
\hline CCSM4 & 27.9 & 6.3 & 3.8 & 47.7 & 49 & 6.87 & 16.5 \\
\hline CNRM-CM5 & 27.3 & 5.5 & 3.68 & 41.1 & 41.2 & 6.68 & 15.2 \\
\hline GFDL- CM3 & 27.4 & 5.8 & 3.99 & 43.4 & 46.4 & 6.8 & 14.8 \\
\hline GFDL-ESM2G & 27 & 5.8 & 3.7 & 41.9 & 45.3 & 8.6 & 13.6 \\
\hline GISS-E2-R & 28.8 & 5.1 & 4.0 & 39.17 & 47.4 & 6 & 12.8 \\
\hline IPSL LR & 27.7 & 4.46 & 3.4 & 40.3 & 46.3 & 8.4 & 11.7 \\
\hline NorESM1 & 27.2 & 5.84 & 3.5 & 43.84 & 49 & 7.6 & 16.7 \\
\hline Ensemble mean & 27.6 & 5.54 & 3.7 & 42.5 & 46.37 & 7.3 & 14.5 \\
\hline
\end{tabular}

(b) Future change (expressed in \%)

\begin{tabular}{|c|c|c|c|c|c|c|c|}
\hline Models & $\begin{array}{l}\text { Surf. Tmp. } \\
\quad\left({ }^{0} \mathbf{C}\right)\end{array}$ & $\begin{array}{c}\text { Pave } \\
\left(\mathbf{m m ~ d a y ~}^{-1}\right)\end{array}$ & $\underset{\left(\text { mm day }^{-1}\right)}{\text { Evap. }}$ & $\begin{array}{c}\mathbf{C W C} \\
\left(\mathbf{k g ~ m}^{-2}\right)\end{array}$ & $\begin{array}{c}\text { Atmo. } \\
\text { Stab. } \\
\left({ }^{0} \mathbf{K}\right)\end{array}$ & $\underset{\left(\mathbf{m ~ s}^{-1}\right)}{\mathbf{U}}$ & $\underset{\left(\mathrm{m} \mathrm{s}^{-1}\right)}{\mathrm{MHC}}$ \\
\hline CCSM4 & 5.0 & 9.5 & 5.4 & 12.4 & 8.4 & -14.55 & -3.0 \\
\hline CNRM-CM5 & 6.2 & 5.45 & 6.52 & 14.6 & 11.9 & -4.5 & -0.66 \\
\hline GFDL- CM3 & 10.2 & 10.3 & 8.4 & 26.3 & 10.34 & -5.9 & -5.5 \\
\hline GFDL-ESM2G & 5.9 & 7.24 & 5.41 & 13.1 & 9.3 & -6.98 & -3.0 \\
\hline GISS-E2-R & 4.86 & 8.0 & 5.0 & 11.67 & 8.7 & -10 & 4.6 \\
\hline IPSL LR & 9 & 10.76 & 8.83 & 21.9 & 10.2 & -11.9 & -0.9 \\
\hline NorESM1 & 4.8 & 9.93 & 8.57 & 13.6 & 10.6 & -14.5 & -3.7 \\
\hline Ensemble mean & 6.5 & 8.4 & 5.4 & 16.23 & 9.89 & -9.77 & -2.1 \\
\hline
\end{tabular}

